\title{
Moringa oleifera Protects SH-SY5YCells from DEHP-Induced Endoplasmic Reticulum Stress and Apoptosis
}

\author{
Ines Amara ${ }^{1,2,+}$, Maria Laura Ontario ${ }^{1,+}{ }^{\dagger}$, Maria Scuto ${ }^{1,3} \mathbb{C}$, Gianluigi Maria Lo Dico ${ }^{1} \mathbb{C}$, Sebastiano Sciuto ${ }^{1}$, \\ Valentina Greco ${ }^{1}{ }^{1}$, Salwa Abid-Essefi ${ }^{2}$, Anna Signorile ${ }^{4, *}$, Angela Trovato Salinaro ${ }^{1, *(1)}$ and \\ Vittorio Calabrese ${ }^{1}$ (D)
}

1 Department of Biomedical and Biotechnological Sciences, University of Catania, Torre Biologica, via Santa Sofia 97, 95125 Catania, Italy; ines.amara15@yahoo.fr (I.A.); marialaura.ontario@ontariosrl.it (M.L.O.); mary-amir@hotmail.it (M.S.); gigilodico@gmail.com (G.M.L.D.); ssciuto@unict.it (S.S.); vgreco@unict.it (V.G.); calabres@unict.it (V.C.)

2 Laboratory for Research on Biologically Compatible Compounds, Faculty of Dental Medicine, University of Monastir, Rue Avicenne, Monastir 5019, Tunisia; salwaabid@yahoo.fr

3 Pathology Unit, Centro di Riferimento Oncologico di Aviano (CRO) IRCCS, 33081 Aviano, Italy

4 Department of Basic Medical Sciences, Neurosciences and Sense Organs, University of Bari, Piazza G. Cesare, 11, 70124 Bari, Italy

* Correspondence: Anna.signorile@uniba.it (A.S.); Trovato@unict.it (A.T.S.)

+ Co-first Authorship.

Citation: Amara, I.; Ontario, M.L.; Scuto, M.; Lo Dico, G.M.; Sciuto, S.; Greco, V.; Abid-Essefi, S.; Signorile, A.; Salinaro, A.T.; Calabrese, V. Moringa oleifera Protects SH-SY5YCells from DEHP-Induced Endoplasmic Reticulum Stress and Apoptosis. Antioxidants 2021, 10, 532. https://doi.org/10.3390/ antiox10040532

Academic Editors: Gunter Peter Eckert and Uwe Wenzel

Received: 3 January 2021

Accepted: 19 March 2021

Published: 29 March 2021

Publisher's Note: MDPI stays neutral with regard to jurisdictional claims in published maps and institutional affiliations.

Copyright: (c) 2021 by the authors. Licensee MDPI, Basel, Switzerland. This article is an open access article distributed under the terms and conditions of the Creative Commons Attribution (CC BY) license (https:// creativecommons.org/licenses/by/ $4.0 /)$.

\begin{abstract}
Moringa oleifera (MO) is a medicinal plant that has been shown to possess antioxidant, anticarcinogenic and antibiotic activities. In a rat model, MO extract (MOe) has been shown to have a protective effect against brain damage and memory decline. As an extending study, here, we have examined the protective effect of MOe against oxidative stress and apoptosis caused in human neuroblastome (SH-SY5Y) cells by di-(2-ethylhexyl) phthalate (DEHP), a plasticizer known to induce neurotoxicity. Our data show that MOe prevents oxidative damage by lowering reactive oxygen species (ROS) formation, restoring mitochondrial respiratory chain complex activities, and, in addition, by modulating the expression of vitagenes, i.e., antioxidant proteins Nrf2 and HO-1. Moreover, MOe prevented neuronal damage by partly inhibiting endoplasmic reticulum (ER) stress response, as indicated by decreased expression of CCAAT-enhancer-binding protein homologous protein (CHOP) and Glucose-regulated protein 78 (GRP78) proteins. MOe also protected SH-SY5Y cells from DEHP-induced apoptosis, preserving mitochondrial membrane permeability and caspase-3 activation. Our findings provide insight into understanding of molecular mechanisms involved in neuroprotective effects by MOe against DEHP damage.
\end{abstract}

Keywords: di-(2-ethylhexyl) phthalate; Moringa oleifera; endoplasmic reticulum stress; vitagenes; oxidative stress; apoptosis; mitochondrial respiratory complexes

\section{Introduction}

Di-(2-ethylhexyl) phthalate (DEHP) belongs to the class of phthalates, which are widely employed as plasticizers to impart elasticity to polymer products [1]. This property is at the origin of the variety of its applications: in the domestic field (wall coverings, leather goods), food (food and beverage packaging), medical (infusion bags, tubing devices), and cosmetic [2]. Human exposure to DEHP may arise via food, air, or medical devices, as this phthalate is easily absorbed through all exposure routes. Various adverse effects have been associated with DEHP exposure, namely neurotoxicity, reprotoxicity, nephrotoxicity, hepatotoxicity, and endocrine disruption [3-6]. DEHP-induced neurotoxicity involves several cellular mechanisms such as oxidative stress, nuclear factor erythroid 2-related factor (Nrf2) pathway, mitochondrial dysfunctions, and apoptosis [7,8]. Moreover, it has been reported that, at particular concentrations, DEHP can exert neurotoxic effects following both prenatal and postnatal exposures. Specifically, in rats, prenatal exposure to DEHP 
disrupts central nervous system development and decreases brain weight [9]. Also, it has been proven that DEHP poses a negative impact on hippocampal development in male rats [10]. Postnatal DEHP exposure is known to cause motor hyperactivity and significantly decreases the number of midbrain dopaminergic neurons [11]. In humans, association between autism spectrum disorders and phthalate exposure has been found [12]. Due to these cellular disturbances and their widedistribution, phthalates attract public concern. In order to limit the toxicity of DEHP, the increase in the consumption of diet components such as vitamins and antioxidants could be considered. Therefore, studies on the effect of antioxidants, particularly those consumed in foods, areconsidered to be of great interest in preventing DEHP-induced cell damage. For centuries, traditional medicine has used medicinal plants which are rich in secondary metabolites, with important biological activities, and phytochemicals used in drugs manufacturing [13]. Moringa oleifera (MO), belonging to the Moringaceae family, is an important source of nutrients because of its high content of bioactive ingredients present in the leaves, seeds and pods of the plant. In fact, $\mathrm{MO}$ provides protein, calcium, potassium, iron, vitamin A, and vitamin C [14]. MO appears to possess various health-promoting properties. The flavonoids and polyphenols contained in MO confer neuroprotective, antioxidant, antibacterial, and anti-inflammatory properties [15-17].It has been demonstrated that MO extract (MOe) exerts protective effects on many organs, including liver, reproductive system, and central nervous system [18-20]. The use of MOe at different concentrations and incubation times makes this compound very versatile and itcan also have antiproliferative/anticancer activity [21]. The potential anticancer effect of MOe has also been investigated, in vivo, where MO extract administration was able to reduce the tumor weight and the volume of tumor-bearing mice, while increasing the lifespan [22], as well as in vitro in cancerous human alveolar epithelial cells [23]. Antiproliferative activity has been reported for isolated bioactive compound and/or enriched extracts from MOe. In a model of lead-induced liver damage and inflammation, MOe prevented oxidative stress, an affect associated with decreased nuclear factor kappa-light-chain-enhancer of activated B cells NF-kB levels, inflammation, and apoptosis [24]. Increasing evidence reports that $\mathrm{MO}$ activates phase 2 response, resulting in expression of the Nrf2/heme oxygenase 1 (HO-1) antioxidant pathway [25]. Interestingly, Nrf2 (nuclear factor erythroid 2-related factor) represents an essential defensive mechanism against oxidative stress and mitochondrial dysfunction [26,27]. Nrf2, under physiological conditions, is localized in the cytosol and kept inactivated by binding to its inhibitor Kelch-like ECH-associated protein 1 (Keap1). Exposure to DEHP induces cytotoxicity associated with reactive oxygen species (ROS) generation, leading to Nrf2 translocation and accumulation into the nucleus where, by binding to the antioxidant response element (ARE), it promotes transcription of multiple target genes, which include phase II detoxification enzymes, NAD(P)H:quinone oxidoreductase 1 (NQO1), heme oxygenase 1 (HO-1), and glutathione S-transferase (GST) P, Pi, and A1 isoforms [28-31]. In addition, the Nrf2 promoter also contains ARE sequences, making its transcript level also a marker of Nrf2 pathway status. In line with these observations, Nrf2 encodes vitagene antioxidant pathways able to counteract different forms of stress (e.g., oxidative, environmental, and endoplasmic reticulum (ER) stress). The latter involves redox-sensitive genes, such as heme oxygenase-1 (HO-1), heat shock proteins (Hsps), thioredoxin, and the sirtuinsystem, termed vitagenes [32-34]. Notably, recent evidence suggested that polyphenols from plant and fungal species activate the Nrf2/HO-1 pathway, conferring cytoprotection against ROS generation in a hormetic-like manner [35-42]. HO-1 catalyzes the conversion of heme to biliverdin, ferrous iron, and carbon monoxide, which can directly scavenge free radicals. Interestingly, our recent in vivo and in vitro studies with mushrooms polyphenols have demonstrated their neuroprotective effects by modulation of stress-responsive vitagenes in different brain regions of rats [43-45], as well as in pheochromocytoma 12 (PC12) cells against DEHP-induced neurotoxicity [46]. Hence, the present research was designed to examine the efficacy of MOe in protecting human neuroblastome cells against toxic effects induced by DEHP. In particular, we have analyzed the effect of pretreatment 
of MO on DEHP-induced oxidative stress, mitochondrial dysfunctions, antioxidant protein deregulation, and apoptosis.

\section{Materials and Methods}

\subsection{Chemicals and Reagents}

Ammonium acetate, acetone, and 2-propanol and formic acid werepurchased from Carlo Erba (Milan, Italy). Standard solutions of vanillic acid, syringic acid and chlorogenic acid were purchased from Extrasynthese (Genay Cedex, France). Acetonitrile and methanol were purchased from Merck (Darmstadt, Germany). The solid-phase extraction SPE cartridges used were Waters Oasis Hydrophilic-Lipophilic Balance (HLB) (200 mg) and ultrapure deionized water, with resistivity of $18.2 \mathrm{M} \Omega \mathrm{cm}$, obtained from the Milli- $Q^{\circledR}$ Integral water purification system with Q-pod (Millipore, Bedford, MA, USA). All solutions were filtered through 0.45 membranes (Millipore, Bedford, MA, USA) and degassed before use. Ferulic acid, gallic acid, kaempferol, quercetin, and rutin, N,O-bis(trimethylsilyl)trifluoroacetamide plus $1 \%$ of trimethylchlorosilane, Di(2-ethylhexyl)phthalate, Dulbecco's modified eagles Medium (DMEM) high glucose, $2^{\prime}, 7^{\prime}$-dichlorodihydrofluoresceine diacetate (DCFH2-DA), 3-4,5-dimethylthiazol-2-yl,2,5-diphenyltetrazolium bromide (MTT), phosphate buffer saline (PBS), fetal bovine serum (FBS), streptomycin and penicillin mixture, and trypsin-Ethylened iaminetetraacetic acid (EDTA) were acquired from Sigma-Aldrich S.r.l. (Milan, Italy).

2.2. Moringa Preparation, Extraction, and Analysis by Gas Chromatography-Tandem Mass Spectrometry (GC-MS/MS) and Liquid Chromatography_Tandem Mass Spectrometry (LC-MS/MS)

Moringa (Moringa oleifera Lamk.) sprouts powder was supplied by EDYNEA (Vicenza, Italy). Powder from MO was obtained according to the process described in the registered patent (WO/2020/021071), which relates to a process for the preparation of a raw material enriched with isothiocyanates, which are known for their anti-inflammatory properties, and polyphenols, which are known for their antioxidant action, starting from Moringa sprouts by soilless cultivation and/or form sprouts harvested from the adult plant. In brief, the preparation of Moringa sprouts from seeds comprises selection of seeds, germination, and growth under controlled soilless conditions, harvesting of aerial parts, seed, and root residues. The preparation of the powder from sprouts obtained by the process described above proceeds with washing of the aerial parts and extraction by a screw extractor to obtain a solid phase and a liquid phase, which are homogenized and then subjected to a freeze-drying process to yield, after grinding, the final powder preparation. Extraction of polyphenol compounds was accomplished by dissolving two $0.125 \mathrm{~g}$ aliquots of $\mathrm{MO}$ powder in $10 \mathrm{~mL}$ of methanol and $10 \mathrm{~mL}$ of acetonitrile respectively, in an orbital shaker incubated (Professional 3500 Orbital Shaker, VWR International Srl, Milan, Italy) at $5{ }^{\circ} \mathrm{C}$ for $24 \mathrm{~h}$.The extracts were then filtered using a $0.45 \mu \mathrm{m}$ syringe filter (Thermo Fisher Scientific Inc., Waltham, MA, USA).The filtrateswere then loaded onto the SPE cartridges, which had been pre-conditioned by treating them, in sequential order, with $4 \mathrm{~mL}$ of methanol and $2 \mathrm{~mL}$ of deionized water.After washing with $2 \times 10 \mathrm{~mL}$ of water, compounds of interest were eluted with $1 \mathrm{~mL}$ of methanol for high-performance liquid chromatography - tandem mass spectrometry (HPLC-MS/MS) analysis and $1 \mathrm{~mL}$ of acetonitrile for GC-MS/MS analysis.

To perform HPLC-MS/MS analysis, a Q-Exactive Plus Hybrid Quadrupole-Orbitrap ${ }^{\mathrm{TM}}$ Mass Spectrometer (Thermo Fisher Scientific, Waltham, MA, USA), equipped with a HESI (Heated ElectroSpray Ionization) source, was used.Analyses wererunin both positive and negative modes in order to determine the exact mass of each analyte. Mass spectrometer parameters were: sheath gas flow rate, 35 (arbitrary units); auxiliary gas flow rate, 10 (arbitrary units); spray voltage, $3.50 \mathrm{kV}$; capillary temperature, $300{ }^{\circ} \mathrm{C}$; tube lens voltage, $55 \mathrm{~V}$; heater temperature, $305^{\circ} \mathrm{C}$; scan mode: full scan; scan range $(\mathrm{m} / \mathrm{z})$ 100-1000; microscans, $1 \mathrm{~m} / \mathrm{z}$; positive resolution: 70,000; Fourier transform (FT) automatic gain control (AGC) target: $3 \times 10^{6}$; negative resolution: 35,000; automatic gain control (AGC) target: $1 \times 10^{6}$; maximum injection time (IT): $100 \mathrm{~ms}$. 
HPLC parameterswere the following: column temperature, $30^{\circ} \mathrm{C}$; sample temperature, $6{ }^{\circ} \mathrm{C}$; flow rate, $0.2 \mathrm{~mL} \mathrm{~min}^{-1}$. The autosampler sample holder temperature was maintained at $7{ }^{\circ} \mathrm{C}$. Mobile phases consisted of eluent A: $30 \mathrm{mM}$ ammonium acetate (pH 5), eluent B: methanol, eluent C: $0.5 \%$ formic acid in water, and eluent D: acetonitrile/acetone/2propanol $(4: 3: 3, v / v / v)$. Mobile phases $B, C$, and D were required for the on-line cleanup of the analytes onTurboFlow ${ }^{\mathrm{TM}}$, whilemobile phases $\mathrm{A}$ and $\mathrm{B}$ were used to perform the subsequent analytical separation. The sample injection volume was $5 \mu \mathrm{L}$.

The two on-line columns Cyclone P column $(50 \mathrm{~mm} \times 0.5 \mathrm{~m}, 60 \mu \mathrm{m}$ particle size, $60 \AA$ pore size, Thermo Fisher Scientific, Waltham, MA, USA) and Hypersil Gold $(2.1 \times 100 \mathrm{~mm}$, $1.7 \mu \mathrm{m}$ particle size) were eluted by the same gradient program according toLópezGutiérrezet al. and Lo Dico et al., with some modifications [45,47].The total run time was $10 \mathrm{~min}$. Data analysis was performed using Thermo Scientific XCalibur (Thermo Fisher Scientific, Waltham, MA, USA) version 4.0 software and Qual Browser.

GC-MS/MS analyses were carried out using a Thermo Scientific TSQ-Quantum XLS Triple Quadrupole gas chromatography mass spectrometry system, equipped with a TR-5MS column $5 \%$ phenyl methyl siloxane, $30 \mathrm{~m} \times 250 \mu \mathrm{m} \times 0.25 \mu \mathrm{m}$. Samples were trimethylsilyl (TMS)-derivatized prior to gas chromatography and $5 \mu \mathrm{L}$ of each samplewasinjected into a Programmed Temperature Vaporizer (PTV). MS acquisition time was 5-45.00 min in full scan mode [50-1000 atomic mass unit (amu)], with scan time 0.272 , and Q1 peak width $0.70 \mathrm{eV}$ in positive and negative polarity. Oven temperatures were: initial holding time of $1.00 \mathrm{~min}$ at $63^{\circ} \mathrm{C}$, rate of $5^{\circ} \mathrm{C} / \mathrm{min}$ up to $330^{\circ} \mathrm{C}$.

\subsection{Cell Culture and Treatment}

Human neuroblastome SH-SY5Y were maintained under their undifferentiated form and cultured in DMEM, 10\% fetal bovine serum (FBS), 1\% L-glutamine (200 mM), $1 \%$ of a mixture of penicillin (100 International Units (IU)/mL) and streptomycin $(100 \mu \mathrm{g} / \mathrm{mL})$, at $37^{\circ} \mathrm{C}$ with $5 \% \mathrm{CO}_{2}$. DEHP stock solution used during this study was $2 \mathrm{mM}$ freshly prepared in pure ethanol before treatments [48]. For the latter, its concentration for treatments never exceeded $0.5 \%$. The MO powder was dissolved in ultrapure water and formulated to $1 \mathrm{mg} / \mathrm{mL}$. The solution was filtered through a $0.22 \mu \mathrm{m}$ microporous membrane and diluted to the desired concentrations $(50-400 \mu \mathrm{g} / \mathrm{mL}$ ) in DMEM. Then, the MOe solutions were stored at $4{ }^{\circ} \mathrm{C}$.

\subsection{Cell Toxicity Assay (MTT Assay)}

SH-SY5Y cells line were seeded on 96-well plates at a density of $25 \times 10^{3}$ cells/well and treated for $24 \mathrm{~h}$ at $37^{\circ} \mathrm{C}$ with different concentrations of DEHP alone, ranging from 5 to $200 \mu \mathrm{M}$ or MO alone $(10-100 \mu \mathrm{g} / \mathrm{mL})$. Cells were also exposed to MOe $(10,50,100$, and $150 \mu \mathrm{g} / \mathrm{mL}) 24 \mathrm{~h}$ prior to DEHP treatment $(55 \mu \mathrm{M})$. At the end of the designed incubation time, the culture medium was removed and replaced by $200 \mu \mathrm{L}$ medium containing $0.5 \mathrm{mg} / \mathrm{mL}$ tetrazolium salt [3-(4,5-dimethylthiazol-2-yl)-2,5-diphenyltetrazolium bromide (MTT)] and incubated for $3 \mathrm{~h}$ at $37^{\circ} \mathrm{C}$. The MTT solution was then eliminated and $100 \mu \mathrm{L}$ of DMSO was added to dissolve the converted purple dye in microplates. The absorbance was measured with a microplate reader spectrophotometer (BioTek, Elx800, Winooski, VT, USA) at a wavelength of $570 \mathrm{~nm}$. Cell viability was expressed as percentage of formazan formation in treated samples as compared to control cells. The half maximal inhibitory concentration (IC50) values were defined as the concentration inducing a 50\% loss of cell viability.

\subsection{Reactive Oxygen Species Determination}

The intracellular ROS levelwas measured by fluorometric assay using permeable $2^{\prime}, 7^{\prime}$-dichlorodihydrofluoresceine diacetate (DCFH2-DA). After diffusion inside the cell, the probe is hydrolyzed by intracellular esterases to non-fluorescent dichlorodihydrofluorescein (DCFH) and then oxidized to fluorescent DCF by ROS or reactive nitrogen species. SH-SY5Y cells were seeded on 24-well culture plates at $10^{5}$ cells / well for $24 \mathrm{~h}$. Then, cells 
were incubated with DEHP $(55 \mu \mathrm{M})$ alone or combined to MO $(100 \mu \mathrm{g} / \mathrm{mL})$ after $2 \mathrm{~h}$ pre-treatment. After $24 \mathrm{~h}$ incubation at $37^{\circ} \mathrm{C}$, cells were treated with $20 \mu \mathrm{M}$ DCFH2-DA for $30 \mathrm{~min}$. Finally, cells were washed with the phosphate-buffered saline (PBS) and intracellular production of ROS was measured by fluorometric detection of DCF oxidation on a fluorimeter (Biotek FL $800 \times$ ) with an excitation wavelength of $485 \mathrm{~nm}$ and emission wavelength of $522 \mathrm{~nm}$. The DCF fluorescence intensity is proportional to the intracellular ROS content.

\subsection{Measurement of Mitochondrial Complex Activities}

Complex I, II-III, IV and complex V activities were assayed in mitochondrial membraneenriched fractions obtained from SH-SY5Y cells. The cells were trypsinized, washed with ice-cold PBS, frozen in liquid nitrogen, and kept at $-80^{\circ} \mathrm{C}$ until use. To prepare the mitochondrial membrane-enriched fractions, cell pellets were thawed at $2-4{ }^{\circ} \mathrm{C}$, suspended in $1 \mathrm{~mL}$ of $10 \mathrm{mM}$ Tris- $\mathrm{HCl}$ ( $\mathrm{pH} 7.5)$, supplemented with $1 \mathrm{mg} / \mathrm{mL} \mathrm{BSA}$, and exposed to ultrasound energy for $15 \mathrm{~s}$ at $0{ }^{\circ} \mathrm{C}$. The ultrasound-treated cells were centrifuged for $10 \mathrm{~min}$ at $600 \times g, 4^{\circ} \mathrm{C}$. The supernatant was centrifuged again for10 $\mathrm{min}$ at $14,000 \times \mathrm{g}$, $4^{\circ} \mathrm{C}$, and the mitochondrial membrane-enriched pellet was suspended in $0.1 \mathrm{~mL}$ of PBS. The NADH:ubiquinone oxidoreductase (complex I) activity was assayed, using $50 \mu \mathrm{g}$ of proteins, in $40 \mathrm{mM}$ potassium phosphate buffer, $\mathrm{pH} 7.4,5 \mathrm{mM} \mathrm{MgCl}, 3 \mathrm{mM} \mathrm{KCN}$, $1 \mu \mathrm{g} / \mathrm{mL}$ antimycin, $200 \mu \mathrm{M}$ decylubiquinone, following the oxidation of $100 \mu \mathrm{M} \mathrm{NADH}$ at 340-425 $\mathrm{nm}\left(\Delta \varepsilon=6.81 \mathrm{mM}^{-1} \mathrm{~cm}^{-1}\right)$. The activity was corrected for the residual activity measured in the presence of $1 \mu \mathrm{g} / \mathrm{mL}$ rotenone [49]. Succinate-cytochrome c oxidoreductase (complex II + III) activity was assayed in $25 \mathrm{mM}$ potassium phosphate buffer, $\mathrm{pH} 7.4,5 \mathrm{mM} \mathrm{MgCl}$, in the presence of $20 \mathrm{mM}$ succinate, $2 \mathrm{mM}$ of potassium cyanide (KCN), $65 \mu \mathrm{M}$ decylubiquinone, and $20 \mu \mathrm{M}$ cytochrome $\mathrm{c}$, using $50 \mu \mathrm{g}$ of protein. The cytochrome $\mathrm{c}$ reduction was followed at $550-540 \mathrm{~nm}\left(\Delta \varepsilon=19.1 \mathrm{mM}^{-1} \cdot \mathrm{cm}^{-1}\right)$. The activity of cytochrome c oxidase (complex IV) was measured following the ferrocytochrome c oxidation at 550-540 $\mathrm{nm}\left(\Delta \varepsilon=19.1 \mathrm{mM}^{-1} \mathrm{~cm}^{-1}\right)$. Complex $\mathrm{V}$ activity (Adenosine triphosphate (ATP) hydrolase activity) was measured using an ATP-regenerating system. $100 \mu \mathrm{g}$ of protein were resuspended at $0.1 \mathrm{mg}$ protein/mL in a buffer consisting of $375 \mathrm{mM}$ sucrose, $75 \mathrm{mM} \mathrm{KCl}, 30 \mathrm{mM}$ Tris- $\mathrm{HCl}$ pH 7.4, 3 mM MgCl 2,2 mM Phosphoenolpyruvate (PEP), $55 \mathrm{U} / \mathrm{mL}$ lactate dehydrogenase, $40 \mathrm{U} / \mathrm{mL}$ pyruvate kinase, $0.3 \mathrm{mM}$ NADH. The reaction was started by the addition of $1 \mathrm{mM}$ ATP and the oxidation of NADH was followed at $340 \mathrm{~nm}[50]$.

\subsection{RNA isolation and $q R T-P C R$}

Total RNA was isolated from cultured cells using RNeasy Mini Kit (Qiagen, Hilden, Germany) referring to the manufacturer's instructions. An amount of $1 \mu \mathrm{g}$ was reversetranscribed in cDNA with Variable Input, Linear Output (VILO) SuperScript (Invitrogen, Monza, Italy). Real-time PCR experiments were performed in the StepOne Thermocycler (Applied Biosystems, Monza, Italy). cDNA was amplified using SYBR Green PCR Master Mix (Applied Biosystems, Monza, Italy). After an initial denaturation at $95{ }^{\circ} \mathrm{C}$ for $15 \mathrm{~min}, 40$ cycles of amplification were performed under the following conditions: $94{ }^{\circ} \mathrm{C}$ for $15 \mathrm{~s}, 60{ }^{\circ} \mathrm{C}$ for $30 \mathrm{~s}$, and $72{ }^{\circ} \mathrm{C}$ for $30 \mathrm{~s}$. This experience was repeated 3 times. $\beta$-actin was performed to normalize for differences in RNA input. qRT-PCR primer sequences' primers were obtained from Invitrogen: $5^{\prime}$ ACGGTGGAGTTCAATGAC $3^{\prime}(\mathrm{F})$ and $5^{\prime}$ TGTTGGCTGTGCTTTAGG 3' (R) for Nrf2 (NM_031789.2); 5' GAAGAGGAGATAGAGCGAAAC 3' (F) and 5' TGTGGCTGGTGTGTAAGG 3' (R) for HO-1 (NM_012580.2); 5'-GCGCATGAAGGAGAAAGAAC-3' (F) and 5'-CCAATTGTTCATGCTTGGTG-3 ${ }^{\prime}$ (R) for CHOP (ENSG00000175197); 5'-CATTGGTGGCCGTTAAGAATGACCAG-3' (F) and 5'-AGTATCGAGCGCGCCGTCGC-3' (R) and 5'-CACGGCATTGTCACCAACT -3' (F) and 5'-TCAGTCAGCAGCACAGGAT-3' (R) for $\beta$-actin (NM_001033084.1). Standard curves and validation experiments were performed for each real-time PCR assay, allowing us to use the comparative $\mathrm{Ct}\left(2^{-\Delta \Delta \mathrm{Ct}}\right)$ method to calculate changes in gene expression. 


\subsection{Protein Extraction and Western Blotting}

For protein extraction, the cells were lysed using the buffer containing N-2-hydroxyeth ylpiperazine-N-ethanesulfonic acid (HEPES) $0.5 \mathrm{M}, 0.5 \%$ Nonidet-P40, $1 \mathrm{mM}$ Phenylmethylsulfonyl fluoride (PMSF), $1 \mathrm{mg} / \mathrm{mL}$ aprotinin, and $2 \mathrm{mg} / \mathrm{mL}$ leupeptin, $\mathrm{pH}$ 7.4. Equal amounts of proteins were separated by $12 \%$ Sodium dodecyl sulfate (SDS)-polyacrylamide gel electrophoresis transferred onto nitrocellulosemembrane and then incubated for $1 \mathrm{~h}$ at room temperature in a blocking solution containing $20 \mathrm{mM}$ Tris $\mathrm{pH} 7.4,150 \mathrm{mM} \mathrm{NaCl}$ and Tween 20 (TBS-T), and $2 \%$ milk powder. Membranes were incubated overnight at $4{ }^{\circ} \mathrm{C}$ with appropriate primary antibodies: anti-Nrf2 polyclonal (SC-13032, Santa Cruz Biotech), antiHO-1 (SC-10789, Santa Cruz Biotech Inc.), anti-GRP78 (SC-13539, Santa Cruz Biotech Inc., Dallas, TX, USA), or anti-CHOP (SC-7351, Santa Cruz Biotech Inc.). For protein loading controls, the same membrane was incubated with anti- $\beta$-actin (ab8227, Abcam, Cambridge, UK) for $1 \mathrm{~h}$. Membranes were then incubated with the secondary polyclonal antibody conjugated with horseradish peroxidase for $1 \mathrm{~h}$ at room temperature. The membranes were then washed three times with TBS-T for $5 \mathrm{~min}$. Finally, the membrane was incubated with the Super Signal chemiluminescent detection system kit (Cod34080 Pierce Chemical Co., Rockford, IL, USA) to detect protein bands corresponding to each antibody using Gel Logic 2200 PRO (Bioscience). The immunoreactive bands were analyzed with ImageJ software to determine the relative density (RD). The molecular weight of proteins analyzed was determined using protein molecular weight standards. The result is shown as a ratio between the intensity of the protein tested in the treated cells compared to that in the untreated cells.

\subsection{Mitochondrial Membrane Potential ( $\Delta \Psi m)$ Assay}

Mitochondrial membrane potential is measured according to the cell membrane uptake of the cationic fluorescent dye rhodamine-123. SH-SY5Y cells $\left(25 \times 10^{3}\right.$ cells/well in 96-well plates) were treated with DEHP $(55 \mu \mathrm{M})$ alone or combined to MOe $(100 \mu \mathrm{g} / \mathrm{mL})$ for $24 \mathrm{~h}$. Next, cells were incubated with rhodamine- 123 for $15 \mathrm{~min}\left(37^{\circ} \mathrm{C}, 5 \% \mathrm{CO}_{2}\right)$. The up-taken rhodamine- 123 was detected by fluorimetric detection. The results were expressed as the percentage of rhodamine fluorescence absorbed by the treated cells from the fluorescence measured in the untreated cells.

\subsection{Cell Death Induced by DEHP}

Annexin V/propidium iodide (AnnV/PI) double staining was used to distinguish necrotic from apoptotic cells. The combination of PI and fluorescein isothiocyanate (FITC)AnnV allow to distinguish between viable (AnnV-/PI-), early apoptotic (AnnV+/PI-), and late apoptotic/necrotic (AnnV+/PI+) cells. The Annexin V assay was accomplished based on the manufacturer's instructions (Annexin V-FITC kit, Bender MedSystems, Wien, Austria). Fluorescence of at least 5000 cells was detected by flow cytometerFACSAria III (BD Biosciences, San Jose, CA, USA).

\subsection{Caspase-3 Activity Assay}

Caspase- 3 activity was performed according to the manufacturer's instructions (BD Pharmingen). At half confluence, SH-SY5Y cells were cultured in the presence of DEHP alone $(55 \mu \mathrm{M})$, MOe alone $(100 \mu \mathrm{g} / \mathrm{mL})$, or DEHP with MOe at $37^{\circ} \mathrm{C}$ for $24 \mathrm{~h}$. After lysing cells for $30 \mathrm{~min}$, they wereincubated for $1 \mathrm{~h}$ at $37^{\circ} \mathrm{C}$ with the caspase-3-like proteases substrate Ac-DEVD-AMC (Ac-Asp-Glu-Val-Asp-7Amino-4-methylcoumarin). The aminomethylcoumarin (AMC) released was then quantified using a Perkin-Elmer fluorimeter at an excitation/emission wavelength of $380 / 460 \mathrm{~nm}$. The bicinchoninic acid assay (Pierce, Rockford, IL, USA) was used to measure the total protein content in the lysates and then the results were expressed as the percentage of activity in lysates from control cultures. 


\subsection{Statistical Analysis}

Each experiment was assessed three times separately and results were expressed as the mean \pm standard deviation (SD) of the means. We have used theone-way analysis of variance (ANOVA) test to evaluate differences among groups, followed by Tukey's post hoc test. We have used Student's $t$ test to compare differences between two groups. Differences were considered significant at $p<0.05$.

\section{Results}

\subsection{Analysis of MOe by LC/MS and GC/MS}

Liquid Chromatography/MS (Orbitrap ${ }^{\mathrm{TM}}$ ) analysis (Figure 1) shows the largest relative abundance found as kaempferol $(29 \%)$. Also relevant is the abundance of quercetin $(15 \%)$, followed by ferulic acid (14\%), gallic acid, and chlorogenic acid (11\%). Rutin and vanillic acid were shown to be $3 \%$ and $4 \%$, respectively. A derivatization with trimethysilane was carried out in order to improve the chromatography and the identification of the peaks by GC-MS/MS (Figure 2). Recognition of the analytes was conducted both with the analysis of single standards and with the method of exact masses and convolutions with algorithms. The relative abundance relative to the area of peaks recognized with certainty is shown in Table 1. Gallic acid with a relative abundance of $41 \%$, quercetin $5 \%$, and kaempferol $8 \%$ were detected. Other compounds found in GC are fatty acids, axatanthines, and sterols. The components present in our sample identified through LC/MS and GC/MS chromatographic analysis are shown (Figures 1 and 2).

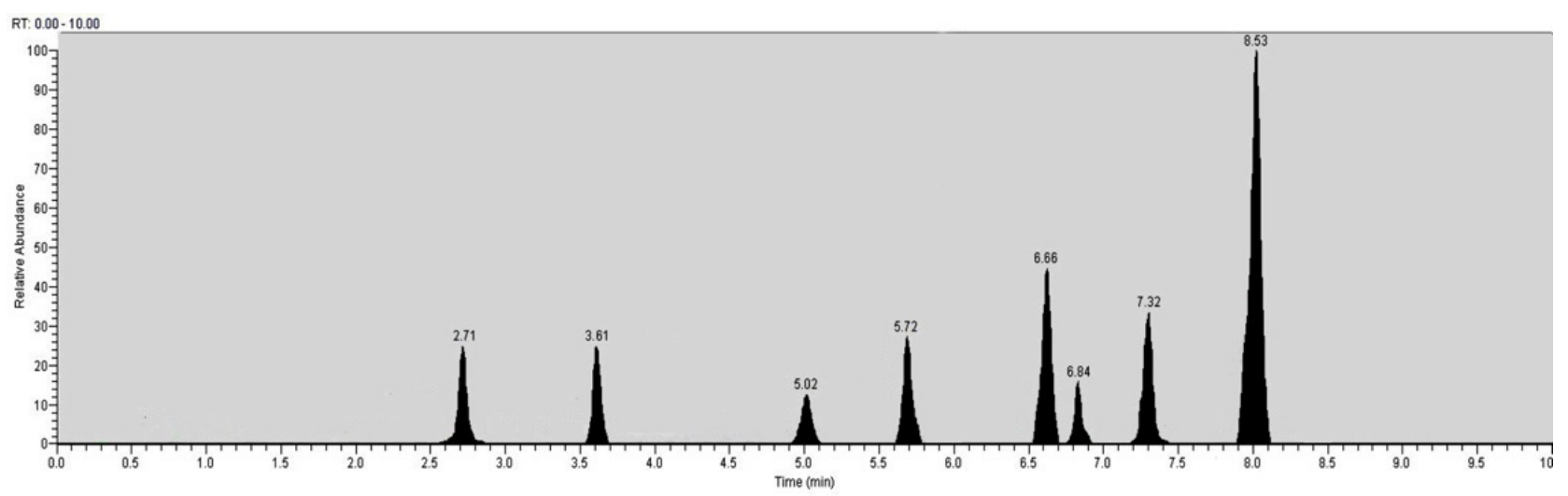

Figure 1. Representative Liquid Chromatography/MS(Orbitrap $\left.{ }^{\mathrm{TM}}\right)$ chromatogram.

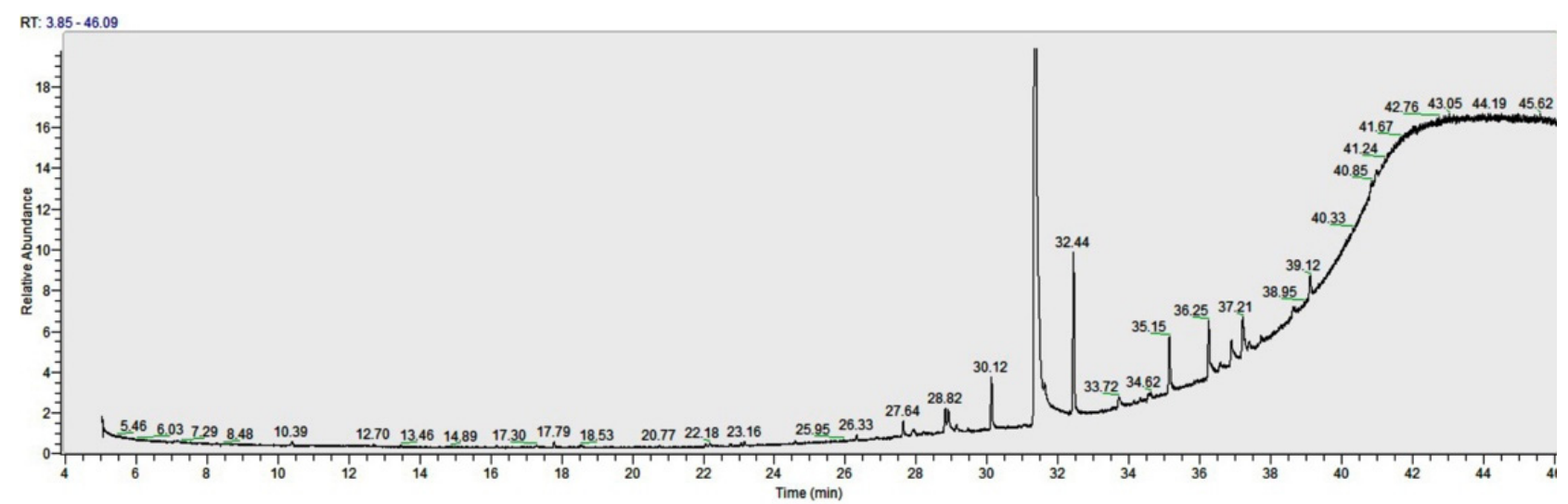

Figure 2. Representative Gas Chromatography-Tandem Mass Spectrometry (GC-MS/MS) chromatogram. 
Table 1. List of identified compounds and accurate masses.

\begin{tabular}{|c|c|c|}
\hline \multicolumn{3}{|c|}{ GC-MS/MS Analysis } \\
\hline Retention Time (minutes) & Name & Relative abundance (\%) \\
\hline 10.39 & Astaxanthin & 0.91 \\
\hline 12.7 & $\begin{array}{c}\text { Carotene, } 1,1^{\prime}, 2,2^{\prime} \text {-tetrahydro- } 1,1^{\prime} \text { - } \\
\text { dimethoxy }\end{array}$ & 0.18 \\
\hline 13.46 & 1-Monolinoleoylglycerol & 1.01 \\
\hline 17.3 & Decanoic acid & 0.19 \\
\hline 17.78 & Rhodopin & 3.05 \\
\hline 19.41 & Destruxin A & 0.19 \\
\hline 20.46 & Hexadecanoic acid, ethyl ester & 0.18 \\
\hline 20.79 & $\begin{array}{l}\text { 5,8,11,14,17-Eicosapentaenoic } \\
\text { acid, methyl ester, }\end{array}$ & 1.05 \\
\hline 22.07 & 9-Octadecynoic acid, methyl ester & 2.01 \\
\hline 22.18 & $\begin{array}{c}\text { Methyl } \\
\text { 8,11,14-heptadecatrienoate }\end{array}$ & 1.09 \\
\hline 27.64 & $\begin{array}{l}\text { 2-Nonadecanone } \\
\text { 2,4-dinitrophenylhydrazine }\end{array}$ & 3.49 \\
\hline 28.82 & Quercetin & 5.31 \\
\hline 30.08 & Gallic acid & 41.8 \\
\hline 32.47 & $\begin{array}{c}\text { Oleic acid, } \\
\text { 3-(octadecyloxy)propyl ester }\end{array}$ & 13.26 \\
\hline 35.14 & Vitamin E & 6.91 \\
\hline 36.25 & Kaempferol & 7.79 \\
\hline 37.21 & $\beta$-Sitosterol & 6.63 \\
\hline 39.12 & Oleyl oleate & 4.95 \\
\hline \multicolumn{3}{|c|}{ LC-Orbitrap $^{\mathrm{TM}}$-MS Analysis } \\
\hline Retention Time (minutes) & Name (accurate masses) & Relative abundance (\%) \\
\hline 2.71 & Gallic acid (168.96) & 11.45 \\
\hline 3.61 & Chlorogenic acid (353.09) & 11.21 \\
\hline 5.02 & Vanillin (150.99) & 4.52 \\
\hline 5.72 & Syringic acid (197.10) & 10.63 \\
\hline 6.66 & Ferulic acid (193.03) & 14.75 \\
\hline 6.84 & Rutin (609.11) & 3.32 \\
\hline 7.32 & Quercetin (301.01) & 15.11 \\
\hline 8.53 & Kaempferol (285.04) & 29.01 \\
\hline
\end{tabular}

\subsection{Effect of MOe on DEHP-Induced Cytotoxicity}

DEHP treatment of SH-SY5Y cells with concentrations ranging from 5 to $200 \mu \mathrm{M}$ caused a significant decrease in the cell viability after $24 \mathrm{~h}$ (Figure 3A). The IC50 value, assessed after $24 \mathrm{~h}$ of cell treatment, was around $55 \mu \mathrm{M}$. Moreover, MOe alone did not cause cytotoxic effects towards SH-SY5Y cells at selected low concentrations (Figure 3B), while pretreatment with MOe for $2 \mathrm{~h}$ at 10, 50, and $100 \mu \mathrm{g} / \mathrm{mL}$ significantly decreased DEHPmediated cytotoxicity (Figure 3C). The high concentration tested of MOe $(150 \mu \mathrm{g} / \mathrm{mL})$ is not toxic towards SH-SY5Y cells, it has shown a viability ranging from $70 \%$ (Figure $3 \mathrm{~B}$ ) to 90\% (Figure 3C). 
(A)

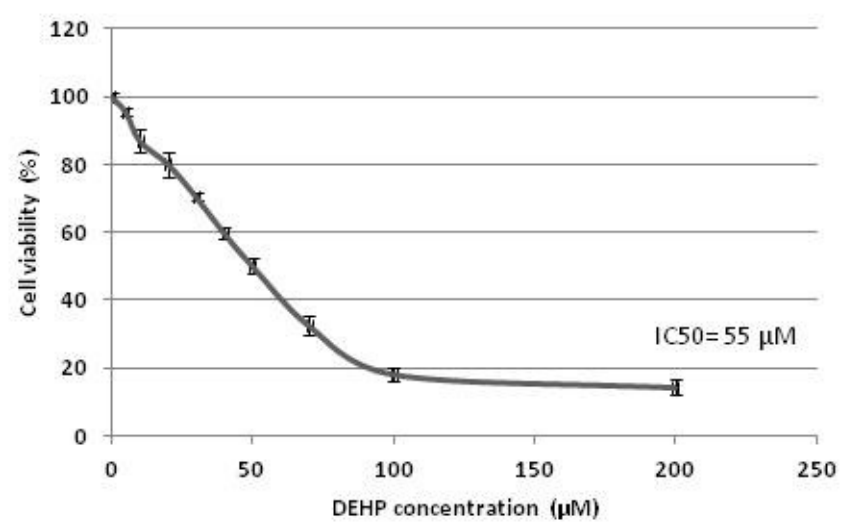

(B)

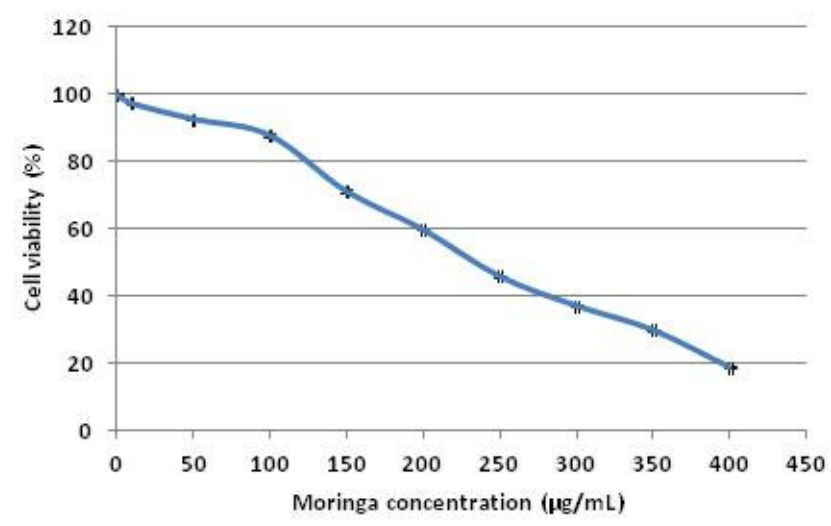

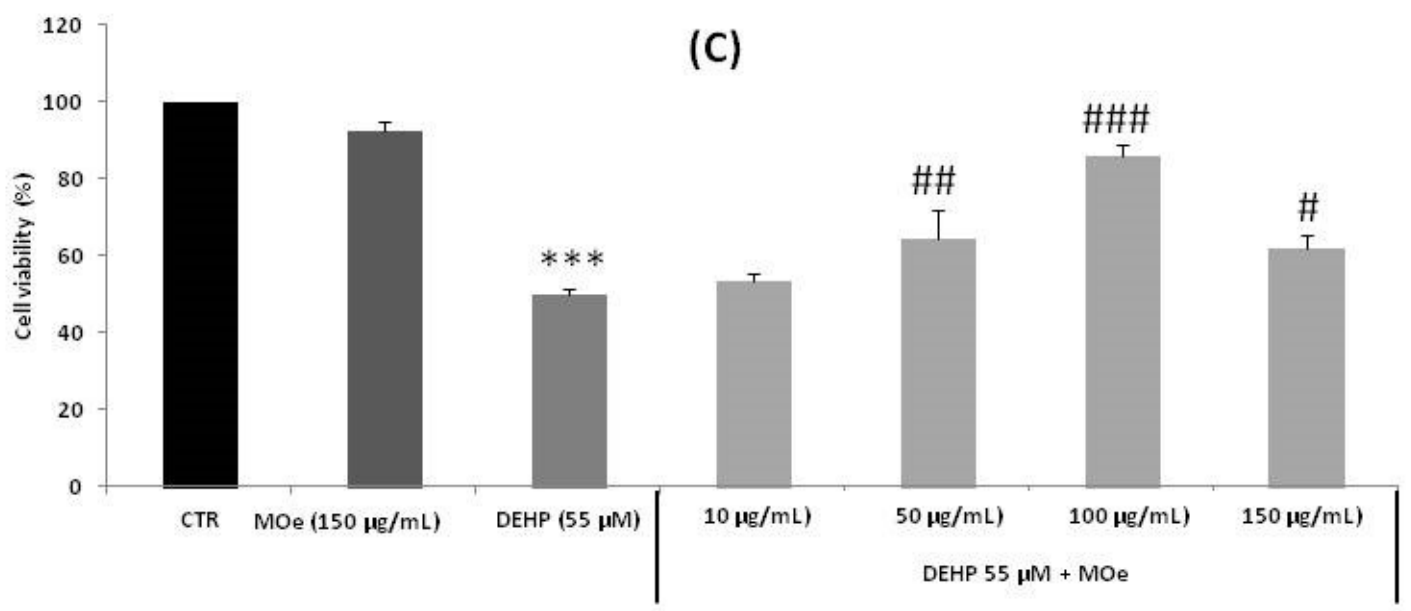

Figure 3. (A,B) Cytotoxic effect of di-(2-ethylhexyl) phthalate (DEHP) and Moringa oleifera extract (MOe) on SH-SY5Y cells. Cells were treated with DEHP or MOe at the indicated concentrations for $24 \mathrm{~h}$. Cell viability was determined using the MTT assay and expressed as percentages of viability. (C) MOe reduces DEHP-induced cytotoxicity in SH-SY5Y. Cells were pretreated for $2 \mathrm{~h}$ with MO $(10,50,100$, and $150 \mu \mathrm{g} / \mathrm{mL})$ before DEHP treatment for $24 \mathrm{~h}(55 \mu \mathrm{M})$. Data are expressed as the mean \pm standard deviation (SD) of three independent experiments. ${ }^{* * *} p<0.001$ vs. control, \#p<0.05, \#\# $p<0.01$, and \#\#\# $p<0.001$ vs. DEHP alone.

\subsection{Effect of MOe on DEHP-Induced ROS Generation}

DEHP toxicity has been related to oxidative stress generation in numerous cell lines. Consequently, we test whether MOe exerts its suggested antioxidant property and modulates ROS level generated by the DEHP in human neuroblastoma cells. Hence, after DEHP treatment, intracellular ROS was measured in the absence or presence of $100 \mu \mathrm{g} / \mathrm{mL}$ of MOe. As show in Figure 4, DEHP treatment induced a marked ROS generation increase ofabout 2.8-folds with respect to the control group. Pre-treatment with MOe at $100 \mu \mathrm{g} / \mathrm{mLw}$ as able to reduce the intracellular ROS generated by DEHP in SH-SY5Y cells.

\subsection{Effect of MOe on DEHP-Induced Mitochondrial Dysfunctions}

It is reported that increased ROS production after DEHP treatment can be associated with mitochondrial dysfunction, thus we analyzed the respiratory chain complex activities I, II-III, IV, and V in SH-SY5Y cells after treatment with DEHP, and then the effect of MOe pretreatment. The data illustrated in Figure 5 show that the DEHP treatment induced mitochondrial dysfunctions, as shown by a decrease in the respiratory complexes' activities 
I, II-III, IV, and V. However, pretreatment with MOe reduces DEHP-induced mitochondrial alterations $(p<0.05)$.

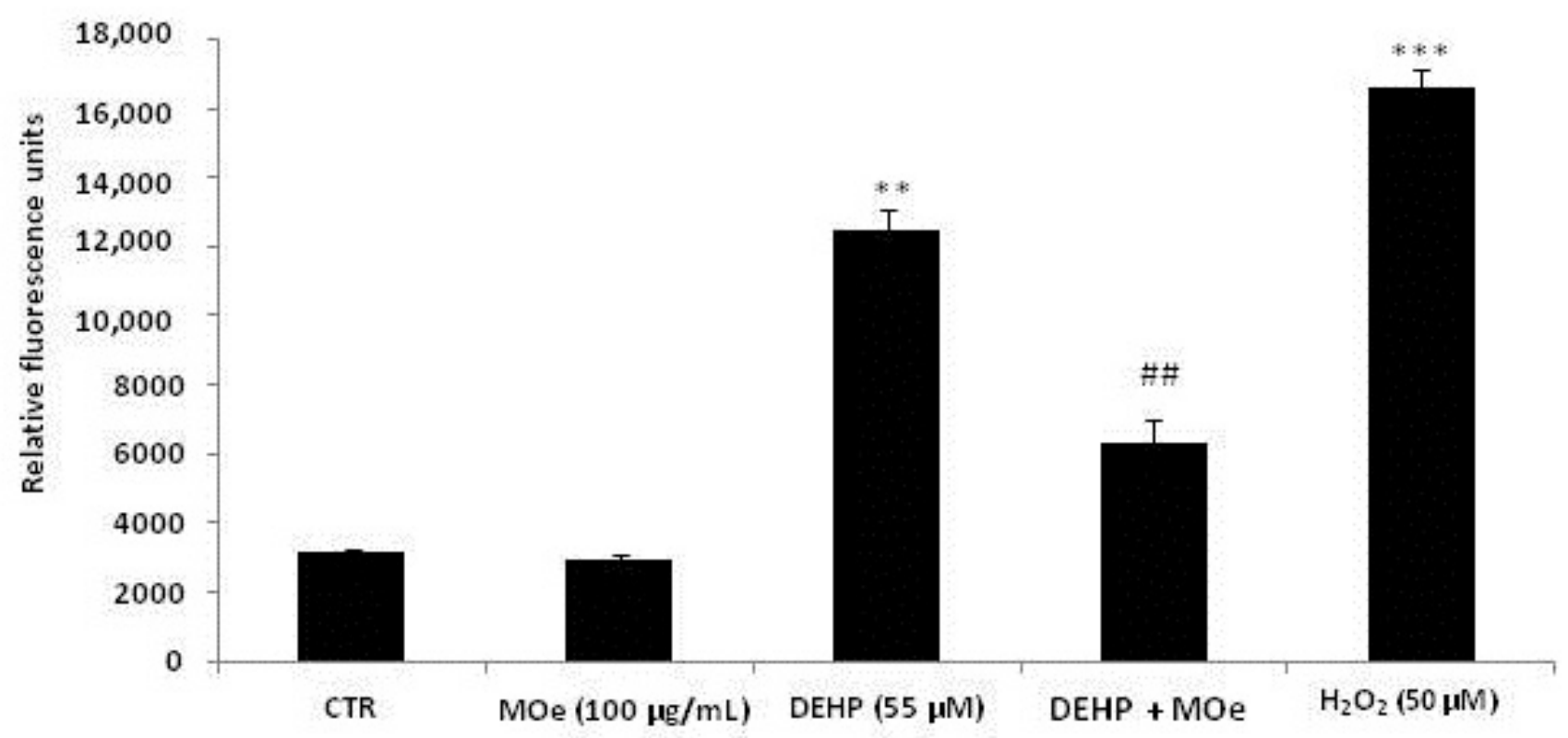

Figure 4. Effect of MOe on DEHP-induced reactive oxygen species (ROS) generation. SH-SY5Y cells were pretreated with MOe $(100 \mu \mathrm{g} / \mathrm{mL})$ for $2 \mathrm{~h}$ before DEHP treatment for $24 \mathrm{~h}(55 \mu \mathrm{M})$ or with $\mathrm{H}_{2} \mathrm{O}_{2}(20 \mu \mathrm{M})$ as a positive control. The relative intracellular ROS production was assessed by measuring the fluorescence of DCF, resulting from the oxidation of DCFH mainly by $\mathrm{H}_{2} \mathrm{O}_{2}$. Data are expressed as the mean $\pm \mathrm{SD}$ of three separate experiments. ${ }^{* *} p<0.01$ vs. control and \#\# $p<0.01$ vs. DEHP alone, ${ }^{* * *} p<0.001$ vs. control.

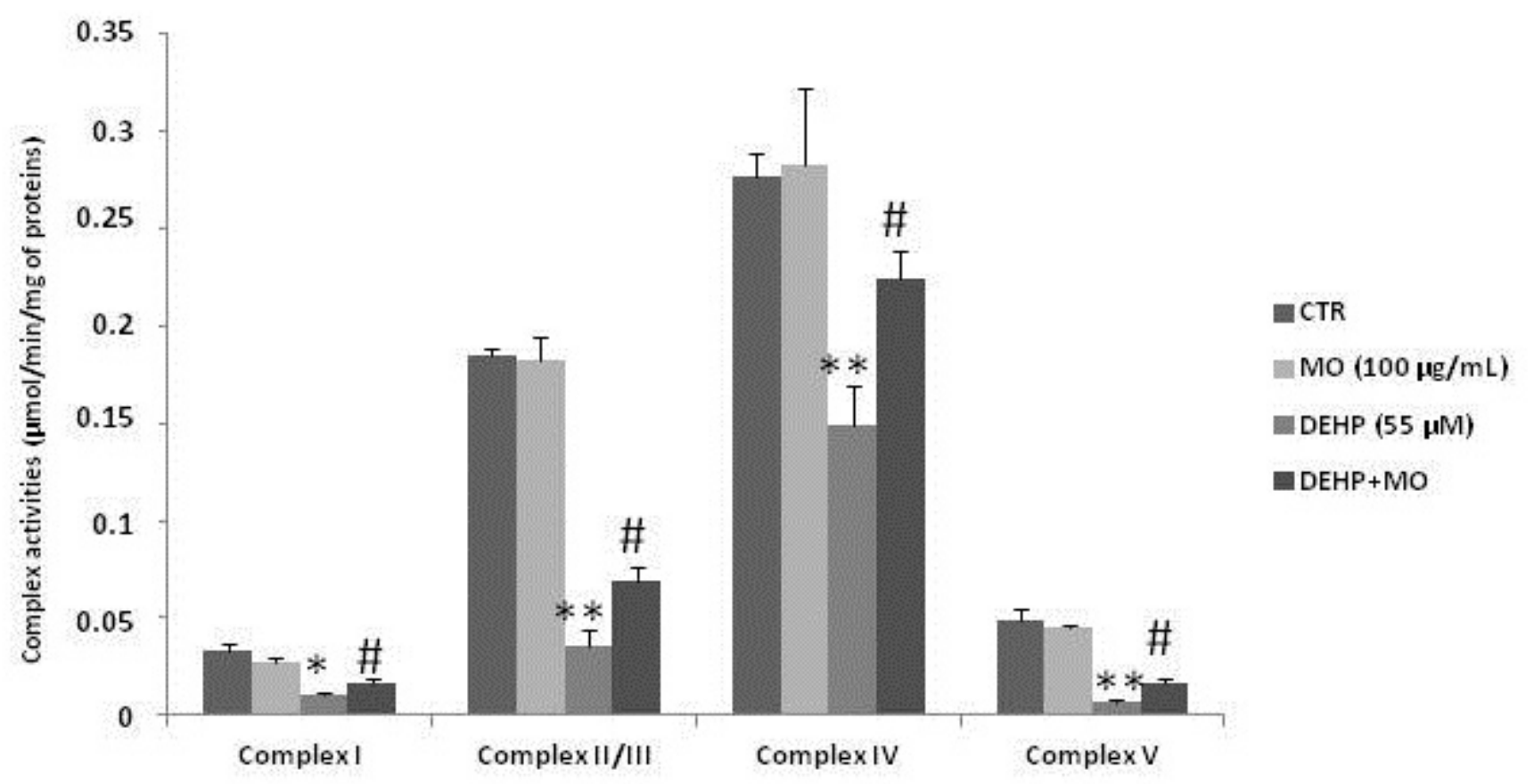

Figure 5. Effect of MOe on DEHP-induced mitochondrial dysfunctions. SH-SY5Y cells were pretreated with MOe $(100 \mu \mathrm{g} / \mathrm{mL})$ for $2 \mathrm{~h}$ before DEHP treatment for $24 \mathrm{~h}(55 \mu \mathrm{M})$. Enzymatic activities of respiratory chain complexes I, II-III, IV, and V were assayed spectrophotometrically. Data are expressed as the mean \pm SD of three separate experiments. ${ }^{*} p<0.05,{ }^{* *} p<0.01$ vs. control, and \# $p<0.05$ vs. DEHP alone. 


\subsection{Effect of MOe on NRF2 and HO-1 Expression}

Under stressful conditions, the transcription factor Nrf2 is activated and leads to the transcription of different cytoprotective downstream genes, including HO-1. We estimated the gene expression of Nrf2 and HO-1 and protein levels in SH-SY5Y cells using quantitative real-time (qRT) PCR and western blot, respectively (Figure 6). Fifty-five $\mu \mathrm{M}$ of DEHP exposure demonstrated a significant increase in Nrf2 and HO-1 gene expression (Figure 6A) and protein level (Figure 6B) compared with the control group. However, pretreatment of cells with MOe for $2 \mathrm{~h}$ modulated their expressions by increasing the relative mRNA expression and the protein amount of NRF2 and HO-1.

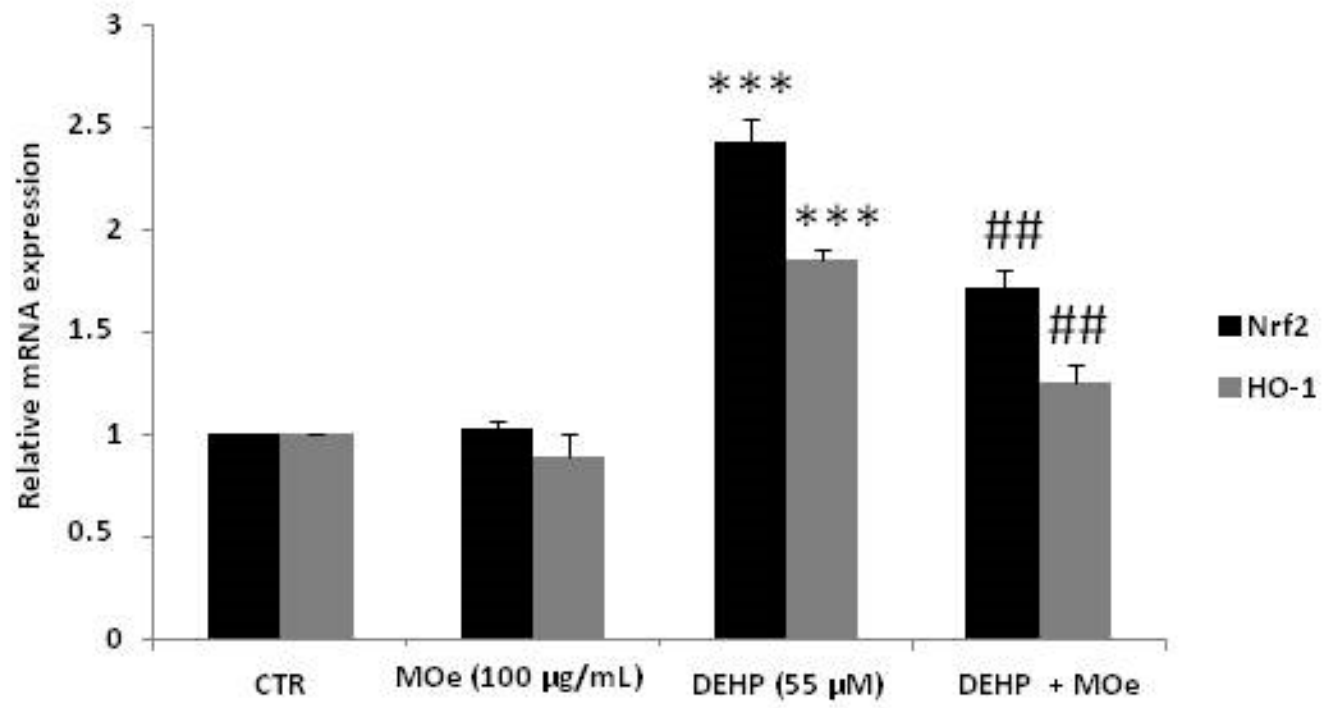

(B)

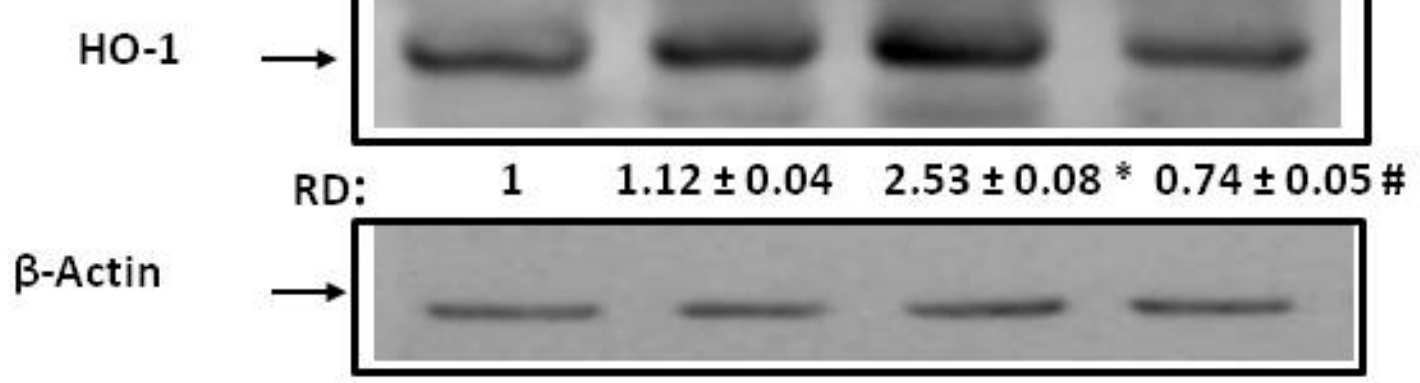

Figure 6. Effect of MOe on DEHP-induced upregulation of Nuclear factor erythroid 2-related factor (Nrf2) and Heme oxygenase 1 (HO-1). SH-SY5Y cells were pretreated with MOe $(100 \mu \mathrm{g} / \mathrm{mL})$ for $2 \mathrm{~h}$ before DEHP treatment for $24 \mathrm{~h}(55 \mu \mathrm{M})$. (A) Nrf2 and HO-1 relative mRNA levels were determined by quantitative Real Time (qRT)-PCR and expressed as fold change over untreated controls (B). As a loading control, we have used $\beta$-actin. RD: relative density as described in the Material and Methods Section.Values represent mean $\pm \mathrm{SD}$ of three independent experiments. ${ }^{*} p<0.05$ vs. control, *** $p<0.001$ vs. control and \# $p<0.05$ vs. DEHP alone, \#\# $p<0.01$ vs. DEHP alone. 


\subsection{Effect of MOe on DEHP-Induced Endoplasmic Reticulum (ER) Stress}

We have evaluated ER stress through the expression measurement of two important markers: GRP78 and CHOP. As indicated in Figure 7A,B, exposure of cells to DEHP $(55 \mu \mathrm{M})$ increased gene and protein expression of these proteins. However, pretreatment with the MOe $(100 \mu \mathrm{g} / \mathrm{mL})$ significantly decreased GRP78 expression and reduced CHOP induction $(p<0.05)$. To confirm that the DEHP induces ER stress, cells were pre-incubated for $2 \mathrm{~h}$ with the chemical chaperone 4-phenylbutyric acid (PBA) prior to DEHP treatment and cell mortality (MTT assay) was determined after $24 \mathrm{~h}$. Consistent with the notion that PBA alleviates ER stress by stabilizing protein conformation [51,52], we observed that PBA significantly decreased cell mortality induced in response to DEHP (Figure 7C).

(A)

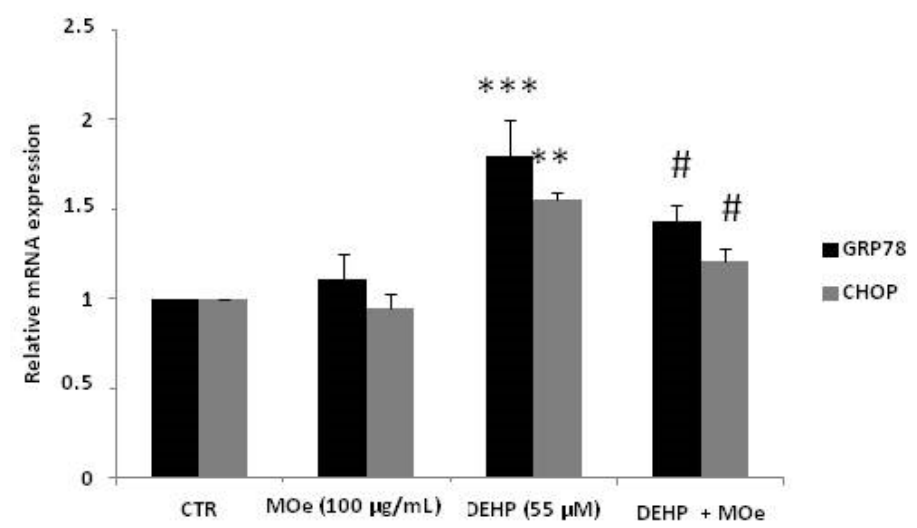

(B)
(C)

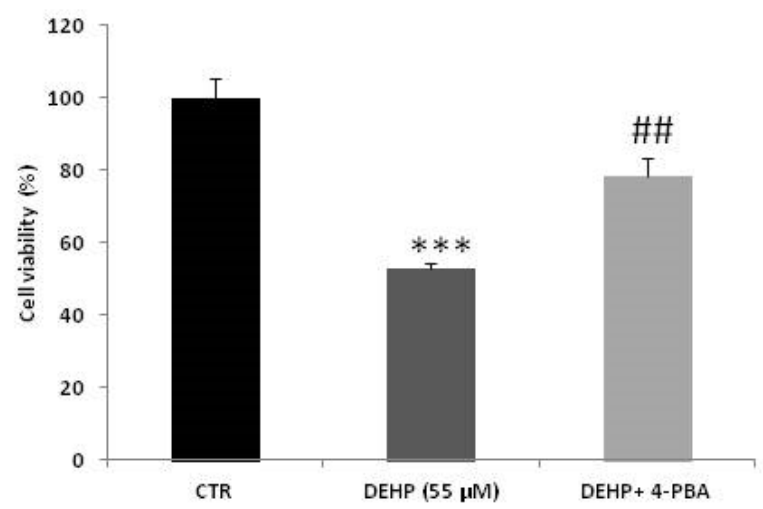

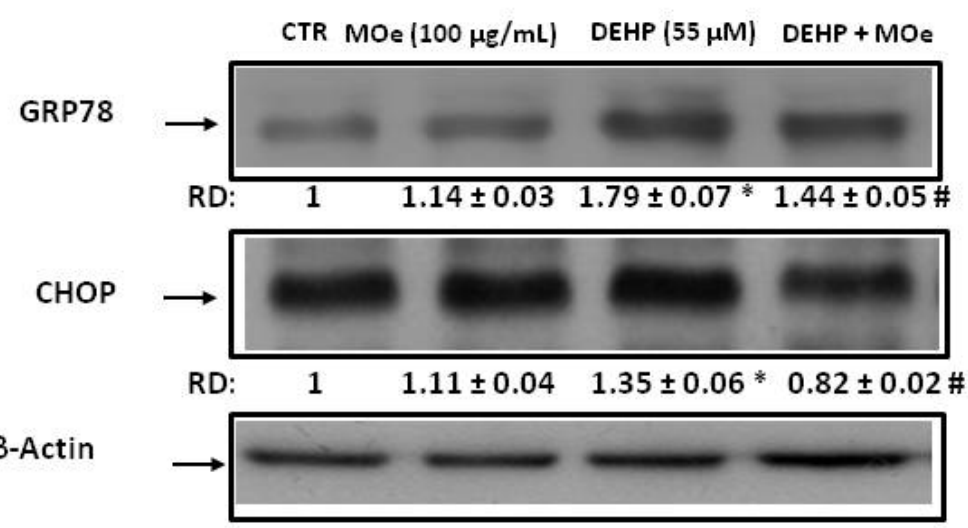

Figure 7. Effect of MOe on DEHP-induced endoplasmic reticulum (ER) stress. SH-SY5Y cells were pretreated with MOe $(100 \mu \mathrm{g} / \mathrm{mL})$ for $2 \mathrm{~h}$ before DEHP treatment for $24 \mathrm{~h}(55 \mu \mathrm{M})$. (A) The glucose-regulated protein 78 (GRP78) and CCAAT-enhancer-binding protein homologous protein (CHOP) mRNA levels were quantified by qRT-PCR and expressed as fold change over untreated controls. As a loading control, we have used $\beta$-actin. (B) GRP78 and CHOP protein levels were quantified by Western blot. RD: relative density as described in the Material and Methods Section. (C) Effect of 4Phenylbutyric acid (4-PBA) pretreatment on SH-SY5Y cell viability. Values represent mean \pm SD of three independent experiments. ${ }^{*} p<0.05,{ }^{* *} p<0.01,{ }^{* * *} p<0.001$ vs. control, and \# $p<0.05, \# \# p<0.01$ vs. DEHP alone.

\subsection{Effect of MOe on DEHP-Induced Cell Death}

On the other hand, it is known that severe ER stress induces apoptosis through the mitochondrial pathway to attenuate damage to cells [53]. Thus, we evaluated Moe's effect on DEHP-induced mitochondrial alterations. Consistent with this purpose, Rh123 was used to measure mitochondrial transmembrane potential $(\Delta \Psi \mathrm{m})$. As shown in Figure $8 \mathrm{~A}$, the percentage of Rh-123 low cells, after $24 \mathrm{~h}$ of DEHP exposure, reached about 
$49.03 \% \pm 1.89 \%$ after treatment with DEHP. Pretreatment of cells by MOe for $2 \mathrm{~h}$ showed a significant decrease of Rh-123 low cells' percentage as compared to cells treated withDEHP alone. These data demonstrate that MOe reduces the DEHP mitochondrial alterations. Moreover, double staining with PI and FITC-labeled-Annexin V allowed us to confirm the apoptosis induced by DEHP using flow cytometry. In comparison to the control values, DEHP at $55 \mu \mathrm{M}$ increased the percentage of early apoptotic cells (AnnV+/PI-) to about $5.41 \%(p<0.05)$ and late apoptotic/necrotic cells $(\mathrm{AnnV}+/ \mathrm{PI}+)$ to about $23.58 \%$ (Figure 8B). However, cell pretreatment with MOe for $2 \mathrm{~h}$ significantly reduced the apoptotic cells rate (Figure 8B). We next assessed the ability of MOe to modulate DEHP-induced caspase activation. As shown in Figure $8 \mathrm{C}$, a significant $(p<0.05)$ increase in caspase-3 activity was observed in SH-SY5Y cells treated with DEHP alone, as compared to untreated cells, indicating that caspases are involved in the apoptotic process caused by the DEHP. Cells' pretreatment with MOe, for $2 \mathrm{~h}$, reduced caspase-3-activation triggered by this phthalate.

(A)

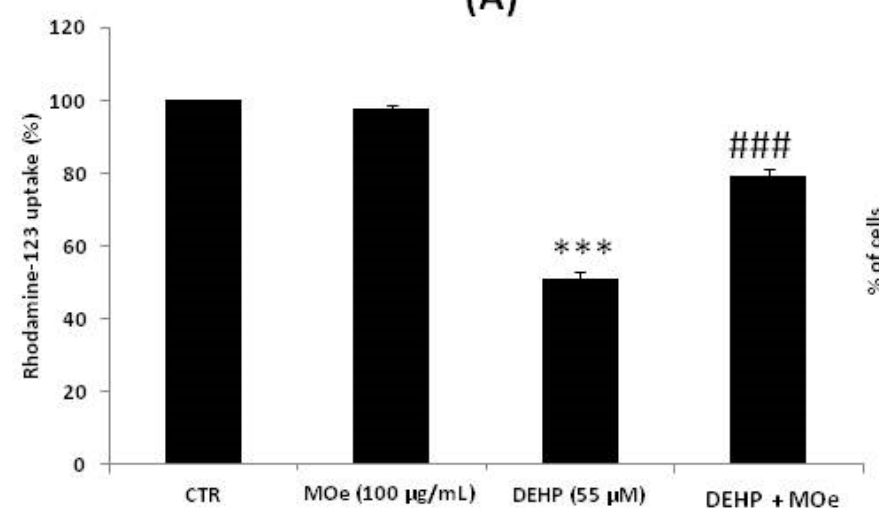

(B)

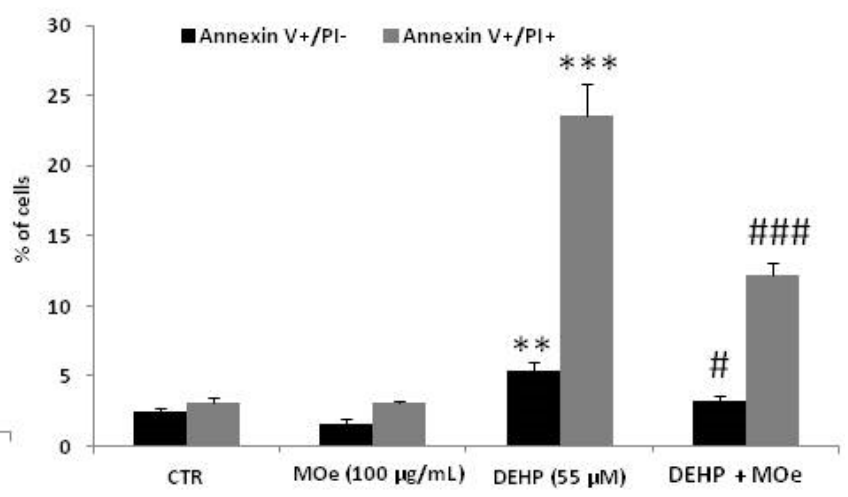

(C)

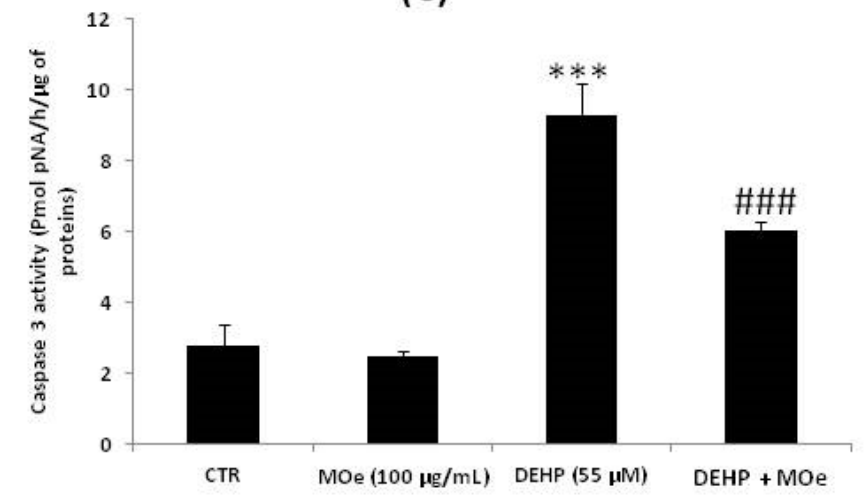

Figure 8. (A) Effect of MOe on DEHP-induced loss of mitochondrial membrane potential. SH-SY5Y cells were pretreated with MOe $(100 \mu \mathrm{g} / \mathrm{mL})$ for $2 \mathrm{~h}$ before DEHP treatment for $24 \mathrm{~h}(55 \mu \mathrm{M})$. After treatment, the mitochondrial potential was evaluated by the Rhodamine-123 uptake measurement. (B) Effects of MOe on DEHP-induced cell apoptosis. Distinct subsets of cells were detected by AnnexinV/ Propidium iodide (PI) staining after treatment with DEHP (55 $\mu \mathrm{M})$ and/or MOe $(100 \mu \mathrm{g} / \mathrm{mL})$. Early apoptotic cells are positive for AnnexinV and negative for PI (AnnV+/PI-) and late apoptotic/necrotic cells are both positive for AnnexinV and PI (AnnV+/PI+). (C) Effect of MOe on DEHP-induced caspase-3 activation. SH-SY5Y cells were pretreated with MOe $(100 \mu \mathrm{g} / \mathrm{mL})$ for $2 \mathrm{~h}$ before DEHP treatment for $24 \mathrm{~h}(55 \mu \mathrm{M})$. Caspase-3 activity was measured using a commercialized kit. Data are expressed as the mean $\pm \mathrm{SD}$ of three separate experiments. ${ }^{* *} p<0.01$, *** $p<0.001$ vs. control, and \# $p<0.05$, \#\#\# $p<0.001$ vs. DEHP alone. 


\section{Discussion}

Phthalates like DEHP remain irreplaceable as plasticizers that are used to impart flexibility and elasticity to polyvinyl chloride products. People are inevitably exposed to phthalates through environmental contamination. Exposure to DEHP has been associated with a variety of toxicological outcomes in mammals, such as reproductive toxicity, neurotoxicity carcinogenicity, hepatotoxicity, and lipid metabolism disruption.

DEHP like phthalates is used to impart elasticity and flexibility. Phthalates are irreplaceable as plasticizers to polyvinyl chloride products. Populations are inevitably exposed to phthalates through environmental contamination. Exposure to DEHP has been correlated with several toxicological outcomes in people, such as neurotoxicity, carcinogenicity, hepatotoxicity, reproductive toxicity, and lipid metabolism disruption [2-6]. The active compounds contained in medicinal plants have gained increasing interest in the protection of human health. In vivo and in vitro studies have demonstrated that plants or plant-derived agents can protect against DEHP-induced toxicity [54-58]. In this study, we investigated the beneficial effects of MOe, known for its antioxidant property, against DEHP-induced toxicity in SH-SY5Y cells. We showed that SH-SY5Y cells are susceptible to DEHP exposure, which results in a decrease in the cell viability compared to the untreated cells. Moreover, we demonstrated that $2 \mathrm{~h}$ pretreatment with MOe significantly increased cell viability altered by the DEHP. Our results also report that treatment of SH-SY5Y cells with DEHP for $24 \mathrm{~h}$ induced overproduction of ROS. These ROS can cause cell damage, resulting in cell death. For this reason, the use of antioxidant molecules and radical scavengers can plausibly prevent cell damage [59]. In fact, pretreatment with MOe $(100 \mu \mathrm{g} / \mathrm{mL})$ significantly protected cells against DEHP-induced oxidative stress by decreasing the ROS production. This result is in agreement with published data demonstrating that MOewas discovered to prevent but also protect against the oxidative stress and cognitive disordersin hyperhomocysteinemia-induced Alzheimer's Disease-like pathology in rats [60]. In addition, it has been recently demonstrated that MOeattenuated titanium oxide nanoparticles-induced brain damage in rats by restraining oxidative stress [20]. This preventive effect against ROS-induced cell damage has also been highlighted in other cellular systems and can therefore be considered a generalized effect.In fact, published data report that MOe protected human neural cells from hydrogen peroxide $\left(\mathrm{H}_{2} \mathrm{O}_{2}\right)$-induced oxidative stress [61]. In addition, it has recently been demonstrated that $\mathrm{MO}$ attenuates the high glucose-induced ROS overproduction in vascular smooth muscle cells (VSMCs) [62], and also, MOe exhibits protection of skin keratinocytes against oxidative stress, by activation of the antioxidant defenses and Peroxisome proliferator-activated receptor alpha $(\mathrm{PPAR} \alpha)$ [63]. Consistent with this finding, MOe exerted a protective role on antioxidant status in heart muscle and lipid peroxidation in streptozocin-induced diabetic models in rats [64]. The observed antioxidant effect of MO is comparable to that tested by other antioxidant molecules: alpha lipoic acid, melatonin, lycopene, and silymarin, that have shown a protective effect against oxidative stress induced by DEHP [65-68].

The increased ROS production can be associated with mitochondrial dysfunction and impairment of mitochondrial electron transport chain function [69,70]. Our results clearly show that DEHP treatment of SH-SY5Y is associated with mitochondrial dysfunction, as revealed by decreased activity respiratory complex I, II-III, IV, and V, and mitochondrial membrane potential. DEHP-induced mitochondrial dysfunction could be associated with several mitochondrial deregulations, such as biogenesis, reduced number of viable mitochondria, and mitochondrial fusion/fission. In addition, the alterations in respiratory complex activities could result from the redoximbalance, which causes degeneration in cells [71].However, further studies are necessary, to define whether DEHP can alsodetermine post-translational and structural modifications of these cellular enzymes. Oxidative stress plays a key role in mitochondrial dysfunctions and could be associated with oxidative modifications of subunits of respiratory chain complexes and modulation/deregulation of their activities [71-73]. On the other hand, our data show that MOe pretreatment could preserve mitochondrial dysfunction, as shown by the effect of MOe on the mitochondrial 
complexes I, II-III, IV, and V, supporting a key role in keeping mitochondrial function, thus renewing the capacity of neurons to produce energy.

The increase of ROS generation is expected to trigger an array of antioxidant systems to maintain cellular homeostasis. Nrf2 is an inducible transcriptional factor upregulating most antioxidant enzymes. Nrf2 is an essential inducer of defense enzymes in cellsand to involve many genes participating in stress-related processes including anti-inflammation, antioxidation, detoxification, metabolism, differentiation, and cell proliferation [74]. To counteract the damage insults, mammalian cells have evolved signaling mechanisms to turn off or on antioxidant responses and cellular adjustments. A well-known endogenous antioxidant response inducedthe activation ofantioxidative and detoxification enzymes through the system Nrf2-Keap1. Under normal conditions, Keap1 stops the Nrf2 factor within the cytoplasm to decrease the levels of Nrf2 that check the constitutive expression of Nrf2 downstream genes. In cells exposed to oxidative imbalance, a signal implying redox modification of critical cysteine residues in Keap1 blocks ubiquitination and proteasomal degradation. In the nucleus, the free Nrf2 translocates and transactivates the antioxidant response elements (AREs) of several cytoprotective genes [75].Thus, cellular expression of $\mathrm{Nrf} 2$ is necessary to identify the susceptibility to oxidative stress. Upregulation of Nrf2 and its target protein $\mathrm{HO}-1$, studied in thisresearch, might be due to the production of oxidative stress created by the DEHP, which, on the other hand, was modulated by MOe pretreatment. Theseresults support the notion that MOe is endowed with neuroprotective activity and is in agreement with another study reporting that MOe alleviated titanium oxide nanoparticles-induced neurotoxicity in rats, as revealed by significant upregulation of Nrf2 and NQO1 mRNA expression [20].

Several evidences have demonstrated that, in Caenorhabditis elegans, the inducible transcription factor skinhead-1 (SKN-1), a homologue of mammalian Nrf proteins, directly controls the ER unfolded protein response (UPR) signaling and controls the transcription factor genes of XBP-1 and ATF-6 [76]. Moreover, responses to oxidative stress mediated by SKN/Nrf were dependenton ER signaling. SKN-1/Nrf was established aspivotal for resistance to ER stress [77]. For this reason, we looked for the implication of ER stress after studying the response of Nrf2.

In the case of exogenous or endogenous stress, the cell could undergo ER stress that activates the UPR. Under ER stress conditions, the cell activates different pathways, Activating transcription factor 6 (ATF-6), and Inositol-requiring enzyme 1(IRE-1), in order to stimulate protein folding, via Binding Immunoglobulin Protein (BiP) induction, and thus decreasing the accumulation of misfolded proteins [78]. Recent studies have confirmed that Nrf2 is also an important downstream target of PERK. PERK phosphorylation activates Nrf2 nuclear translocation [79].

In this study, we demonstrated the involvement of the PERK branch given that the phosphorylation of PERK can activate the Nrf2 pathway [79]. Moreover, it has been observed that extract of $\mathrm{MO}$ leaves exerts a beneficial effect on Caenorhabditis elegans, prolonging the lifespan via activation of DAF-16 (Fork-head domain-containing protein-16), AGE-1 (Phosphatidylinositol 3-kinase age-1), SIR-2.1 (Deacetylase sirtuin-type domaincontaining protein;NAD-dependent protein deacetylase sir-2.1), SKN-1 (Protein skinhead1), and DAF-2 (Insulin-like receptor subunit beta) [80]. Our data showed that treatment with DEHP induced ER stress, as proven by an increase in the expression of the chaperone CHOP and GRP78 mRNA. To better ensure that ER stress is activated by DEHP, we pretreated the cells with the ER stress inhibitor, 4-PBA, $2 \mathrm{~h}$ before exposure to DEHP, and then we tested the cell viability using the MTT assay. Our results prove that ER stress inhibition increased cell viability compared to cells not pretreated with 4-PBA. Different reports have suggested that treatment with DEHP also induces ER stress in human immortalized keratinocyte (HaCaT) cells as well as in mouse testes [81]. In parallel, we observed that $2 \mathrm{~h}$ pretreatment of cells by MOe decreased protein expression of GRP78 and CHOP, indicating that MOe can attenuate the ER stress caused by the DEHP. It was also elucidated that MOe decreased the ER stress in high-fat diet-induced obese mice [82]. In severe stress, the UPR directs the 
cell to death by activating the apoptotic pathway. The CHOP was the transcription factor recognized as a key mediator of ER stress-induced apoptosis and is upregulated by the three UPR branches [83]. An excess of ROS production can induce ER stress and initiate the mitochondrial pathway of apoptosis [84]. The inhibition of the mitochondrial enzyme complexes' activities is an upstream event for the reduction of the mitochondrial membrane potential. An overall decrease in the mitochondrial membrane potential acts as a potent mediator in cell death $[85,86]$. This potential can be reduced in moderate cell damage and enlarge the mitochondrial pores of the outer membrane. This leads to the cytochrome $c$ release into the cytoplasm and triggers apoptosis [84]. Our results indicate that DEHP induces an $\Delta \Psi \mathrm{m}$ dissipation, which can cause a permeabilization of the mitochondrial membrane, and activates a proteolytic enzyme, the caspase-3, which is the major cell death effector protease and is an indicator of apoptotic phenotypes [87].These data suggest that ER stress caused by the DEHP could be associated with the induction of apoptosis via the caspase-dependent mitochondrial pathway. Moreover, our evidence suggests that MOe may prevent DEHP-induced mitochondrial damage by stabilizing membrane potential and decreasing caspase activation in the mitochondrion. A recent paper demonstrated that pretreating human neuron cells with MOe showed a significant resistance to $\mathrm{H}_{2} \mathrm{O}_{2}$-induced apoptotic cell death [88].

\section{Conclusions}

For the first time, in the present work, we reported that MOe exerts neuroprotective effects against DEHP-induced cytotoxicity in SH-SY5Y cells. By reducing ROS production, MOeprotects cells and inhibits the ER stress response from DEHP-induced mitochondrial apoptosis. Increasing interest is emerging on the development of functional compounds capable to modulate cytoprotection and thus provide health-promoting effects. Our results demonstrated the effectiveness of novel approaches in preventing DEHP-induced cell damage and more in general to pursue health-promoting outcomes.

Author Contributions: Conceptualization and methodology: I.A., M.L.O. and M.S.; software, validation, investigation and formal analysis: G.M.L.D., M.L.O., S.A.-E., A.S. and A.T.S.; data curation, writing, original draft preparation: V.C., A.S. and A.T.S.; S.S., V.G., A.S. and A.T.S. contributed to the revision of the manuscript and to the methodology; modified and supervised the final version of the manuscript: V.C., M.L.O., A.S. and A.T.S. All authors have read and agreed to the published version of the manuscript.

Funding: This study was supported by grants from "Piano di incentivi per la Ricerca, Linea Intervento 2 PIACERI, 2020-2022", University of Catania, Italy (V.C., A.T.S.).

Institutional Review Board Statement: Not applicable.

Informed Consent Statement: Not applicable.

Data Availability Statement: All data are presented in the paper.

Acknowledgments: We acknowledge helpful discussion with Giuseppe Dionisio, Aarhus University, Slagelse, Denmark.

Conflicts of Interest: The authors declare no conflict of interest. 


$\begin{array}{ll}\text { Abbreviations } & \\ \text { MO } & \text { Moringa oleifera } \\ \text { SH-SY5Y } & \text { Human neuroblastoma cells } \\ \text { DEHP } & \text { Di-(2-ethylhexyl) phthalate } \\ \text { ROS } & \text { Reactive oxygen species } \\ \text { ER } & \text { Endoplasmic reticulum } \\ \text { Nrf2 } & \text { Nuclear factor erythroid 2-related factor } \\ \text { Keap1 } & \text { Kelch-like ECH-associated protein 1 } \\ \text { ARE } & \text { Antioxidant response element } \\ \text { NQO1 } & \text { NAD(P)H:quinone oxidoreductase 1 } \\ \text { HO-1 } & \text { Heme oxygenase 1 } \\ \text { GST } & \text { Glutathione S-transferase } \\ \text { HSP } & \text { Heat shock proteins } \\ \text { PC12 } & \text { Pheochromocytoma 12 cells } \\ \text { PBA } & \text { Chaperone 4-phenylbutyric acid } \\ \Delta \Psi m & \text { Mitochondrial transmembrane potential } \\ \text { VSMCs } & \text { Vascular smooth muscle cells } \\ \text { Complex I } & \text { NADH:ubiquinone oxidoreductase } \\ \text { Complex II-III } & \text { Succinate-cytochrome c oxidoreductase } \\ \text { Complex IV } & \text { Cytochrome c oxidase } \\ \text { Complex V } & \text { ATP synthase } \\ \text { CTR } & \text { Control } \\ \text { UPR } & \text { Unfolded protein response } \\ \text { DMEM } & \text { Dulbecco's Modified Eagles Medium } \\ \text { FBS } & \text { Fetal Bovine Serum } \\ \text { PBS } & \text { Phosphate Buffer Saline } \\ \text { DCFH-DA } & \text { 2,7-dichlorodihydrofluorescein diacetate } \\ \text { MTT } & \text { 3-4,5-Dimethylthiazol-2-yl,2,5-Diphenyltetrazolium Bromide } \\ \text { DCFH } & \text { Non-fluorescent dichlorodihydrofluorescein } \\ \text { AnnV /PI } & \text { Annexin V/propidium iodide } \\ \text { AMC } & \text { Aminomethylcoumarin } \\ & \\ & \end{array}$

\section{References}

1. Rowdhwal, S.S.S.; Chen, J. Toxic Effects of Di-2-ethylhexyl Phthalate: An Overview. Biomed. Res. Int. 2018, 1, 1750368. [CrossRef]

2. Wang, Y.; Chen, B.; Lin, T.; Wu, S.; Wei, G. Protective effects of vitamin E against reproductive toxicity induced by di(2 ethylhexyl) phthalate via PPAR-dependent mechanisms. Toxicol. Mech. Methods 2017, 27, 551-559. [CrossRef]

3. Chen, H.P.; Pan, M.H.; Chou, Y.Y.; Sung, C.; Lee, K.H.; Leung, C.M.; Hsu, P.C. Effects of di(2-ethylhexyl)phthalate exposure on 1,2-dimethyhydrazine-induced colon tumor promotion in rats. Food Chem. Toxicol. 2017, 103, 157-167. [CrossRef]

4. Pradhan, A.; Olsson, P.E.; Jass, J. Di(2-ethylhexyl) phthalate and diethyl phthalate disrupt lipid metabolism, reduce fecundity and shortens lifespan of Caenorhabditis elegans. Chemosphere 2018, 190, 375-382. [CrossRef]

5. You, M.; Dong, J.; Fu, Y.; Cong, Z.; Fu, H.; Wei, L.; Wang, Y.; Wang, Y.; Chen, J. Exposure to Di-(2-ethylhexyl) Phthalate during Perinatal Period Gender-Specifically Impairs the Dendritic Growth of Pyramidal Neurons in Rat Offspring. Front. Neurosci. 2018, 12, 444. [CrossRef]

6. Amara, I.; Timoumi, R.; Annabi, E.; Di Rosa, G.; Scuto, M.; Najjar, M.F.; Calabrese, V.; Abid-Essefi, S. Di (2-ethylhexyl) phthalate targets the thioredoxin system and the oxidative branch of the pentose phosphate pathway in liver of Balb/c mice. Environ. Toxicol. 2020, 35, 78-86. [CrossRef]

7. Luo, Y.; Li, X.N.; Zhao, Y.; Du, Z.H.; Li, J.L. DEHP triggers cerebral mitochondrial dysfunction and oxidative stress in quail (Coturnix japonica) via modulating mitochondrial dynamics and biogenesis and activating Nrf2-mediated defense response. Chemosphere 2019, 224, 626-633. [CrossRef]

8. Aung, K.H.; Win-Shwe, T.T.; Kanaya, M.; Takano, H.; Tsukahara, S. Involvement of hemeoxygenase-1 in di(2-ethylhexyl) phthalate (DEHP)-induced apoptosis of Neuro-2a cells. J. Toxicol. Sci. 2014, 39, 217-229. [CrossRef]

9. Tanida, T.; Warita, K.; Ishihara, K.; Fukui, S.; Mitsuhashi, T.; Sugawara, T.; Tabuchi, Y.; Nanmori, T.; Qi, W.M.; Inamoto, T.; et al. Fetal and neonatal exposure to three typical environmental chemicals with different mechanisms of action: Mixed exposure to phenol, phthalate, and dioxin cancels the effects of sole exposure on mouse midbrain dopaminergic nuclei. Toxicol. Lett. 2009, 189, 40-47. [CrossRef]

10. Smith, C.A.; Macdonald, A.; Holahan, M.R. Acute postnatal exposure to di(2-ethylhexyl) phthalate adversely impacts hippocampal development in the male rat. Neuroscience 2011, 193, 100-108. [CrossRef] 
11. Masu, Y.; Morita, M.; Oka, S.; Ishido, M. Motor hyperactivity caused by a deficit in dopaminergic neurons and the effects of endocrine disruptors: A study inspired by the physiological roles of PACAP in the brain. Regul. Pept. 2004, 123, 225-234. [CrossRef] [PubMed]

12. Testa, C.; Nuti, F.; Hayek, J.; De Felice, C.; Chelli, M.; Rovero, P.; Latini, G.; Papini, A.M. Di-(2-ethylhexyl) phthalate and autism spectrum disorders. ASN Neuro 2012, 4, 223-229. [CrossRef]

13. El-Shemy, H.A.; Aboul-Enein, A.M.; Aboul-Enein, K.M.; Fujita, K. Willow Leaves' Extracts Contain Anti-Tumor Agents Effective against Three Cell Types. PLoS ONE 2007, 2, e178. [CrossRef]

14. Leone, A.; Fiorillo, G.; Criscuoli, F.; Ravasenghi, S.; Santagostini, L.; Fico, G.; Spadafranca, A.; Battezzati, A.; Schiraldi, A.; Pozzi, F.; et al. Nutritional characterization and phenolic profiling of Moringa oleifera leale grown in chad, sahrawi refugee camps, and haiti. Int. J. Mol. Sci. 2015, 16, 18923-18937. [CrossRef]

15. Rockwood, J.L.; Anderson, B.G.; Casamatta, D.A. Potential uses of Moringa oleifera and an examination of antibiotic efficacy conferred by M. oleifera seed and leaf extracts using crude extraction techniques available to under- served indigenous populations. Int. J. Phytothearpy Res. 2013, 3, 61-71.

16. Mbikay, M. Therapeutic Potential of Moringa oleifera Leaves in Chronic Hyperglycemia and Dyslipidemia: A Review. Front. Pharmacol. 2012, 3, 24. [CrossRef]

17. Edeogu, C.O.; Kalu, M.E.; Famurewa, A.C.; Asogwa, N.T.; Onyeji, G.N.; Ikpemo, K.O. Nephroprotective Effect of Moringa Oleifera Seed Oil on Gentamicin-Induced Nephrotoxicity in Rats: Biochemical Evaluation of Antioxidant, Anti-inflammatory, and Antiapoptotic Pathways. J. Am. Coll. Nutr. 2019, 39, 307-315. [CrossRef] [PubMed]

18. Mousa, A.A.; El-Gansh, H.A.I.; Eldaim, M.A.A.; Mohamed, M.A.E.; Morsi, A.H.; El Sabagh, H.S. Protective effect of Moringa oleifera leaves ethanolic extract against thioacetamide-induced hepatotoxicity in rats via modulation of cellular antioxidant, apoptotic and inflammatory markers. Environ. Sci. Pollut. Res. Int. 2019, 26, 32488-32504. [CrossRef]

19. Elblehi, S.S.; El Euony, O.I.; El-Nahas, A.F. Partial ameliorative effect of Moringa leaf ethanolic extract on the reproductive toxicity and the expression of steroidogenic genes induced by subchronic cadmium in male rats. Environ. Sci. Pollut. Res. 2019, 26, 23306-23318. [CrossRef]

20. Kandeil, M.A.; Mohammed, E.T.; Hashem, K.S.; Aleya, L.; Abdel-Daim, M.M. Moringa seed extract alleviates titanium oxide nanoparticles $\left(\mathrm{TiO}_{2}-\mathrm{NPs}\right)$-induced cerebral oxidative damage, and increases cerebral mitochondrial viability. Environ. Sci. Pollut. Res. Int. 2019. [CrossRef]

21. Cirmi, S.; Ferlazzo, N.; Gugliandolo, A.; Musumeci, L.; Mazzon, E.; Bramanti, A.; Navarra, M. Moringin from Moringa Oleifera Seeds Inhibits Growth, Arrests Cell-Cycle, and Induces Apoptosis of SH-SY5Y Human Neuroblastoma Cells through the Modulation of NF-kB and Apoptotic Related Factors. Int. J. Mol. Sci. 2019, 20, 1930. [CrossRef]

22. Barhoi, D.; Upadhaya, P.; Barbhuiya, S.N.; Giri, A.; Giri, S. Aqueous Extract of Moringa oleifera Exhibit Potential Anticancer Activity and can be used as a Possible Cancer Therapeutic Agent: A Study Involving In Vitro and In Vivo Approach. J. Am. Coll. Nutr. 2020, 40, 70-85. [CrossRef]

23. Tiloke, C.; Phulukdaree, A.; Chuturgoon, A.A. The antiproliferative effect of Moringa oleifera crude aqueosus leaf extract on cancerous human alveolar epithelial cells. BMC Complementary Altern. Med. 2013, 13, 226. [CrossRef]

24. Albasher, G.; Al Kahtani, S.; Alwahibi, M.S.; Almeer, R. Effect of Moringa oleifera Lam. Methanolic extract on lead induced oxidative stress-mediated hepatic demage and inflammation in rats. Environ. Sci. Pollut. Res. Int. 2020, 27, 19877-19887. [CrossRef] [PubMed]

25. Abdou, K.H.; Moselhy, W.A.; Mohamed, H.M.; El-Nahass, E.S.; Khalifa, A.G. Moringa oleifera Leaves Extract Protects Titanium Dioxide Nanoparticles-Induced Nephrotoxicity via Nrf2/HO-1 Signaling and Amelioration of Oxidative Stress. Biol. Trace Elem. Res. 2019, 187, 181-191. [CrossRef]

26. Esteras, N.; Dinkova-Kostova, A.T.; Abramov, A.Y. Nrf2 activation in the treatment of neurodegenerative diseases: A focus on its role in mitochondrial bioenergetics and function. Biol. Chem. 2016, 397, 383-400. [CrossRef] [PubMed]

27. Ryoo, I.G.; Kwak, M.K. Regulatory crosstalk between the oxidative stress-related transcription factor Nfe2l2/Nrf2 and mitochondria. Toxicol. Appl. Pharmacol. 2018, 359, 24-33. [CrossRef] [PubMed]

28. Yu, L.; Li, H.X.; Guo, J.Y.; Huang, Y.Q.; Wang, H.; Talukder, M.; Li, J.L. Di (2-ethyl hexyl)phthalate (DEHP)-induced spleen toxicity in quail (Coturnix japonica) via disturbing Nrf2-mediated defense response. Environ. Pollut. 2019, 251, 984-989. [CrossRef]

29. Yeager, R.L.; Reisman, S.A.; Aleksunes, L.M.; Klaassen, C.D. Introducing the "TCDD-inducible AhR-Nrf2 gene battery". Toxicol. Sci. 2009, 111, 238-246. [CrossRef]

30. Lin, C.Y.; Wu, C.R.; Chang, S.W.; Wang, Y.J.; Wu, J.J.; Tsai, C.W. Induction of the pi class of glutathione S-transferase by carnosic acid in rat Clone 9 cells via the p38/Nrf2 pathway. Food Funct. 2015, 6, 1936-1943. [CrossRef]

31. Bartolini, D.; Galli, F. The functional interactome of GSTP: A regulatory biomolecular network at the interface with the Nrf2 adaption response to oxidative stress. J. Chromatogr. B 2016, 1019, 29-44. [CrossRef] [PubMed]

32. TrovatoSalinaro, A.; Cornelius, C.; Koverech, G.; Koverech, A.; Scuto, M.; Lodato, F.; Fronte, V.; Muccilli, V.; Reibaldi, M.; Longo, A.; et al. Cellular stress response, redox status, and vitagenes in glaucoma: A systemic oxidant disorder linked to Alzheimer's disease. Front. Pharmacol. 2014, 5, 129.

33. Calabrese, V.; Cornelius, C.; Dinkova-Kostova, A.T.; Calabrese, E.J.; Mattson, M.P. Cellular stress responses, the hormesis paradigm, and vitagenes: Novel targets for therapeutic intervention in neurodegenerative disorders. Antioxid. Redox Signal. 2010, 13, 1763-1811. [CrossRef] 
34. Scuto, M.C.; Mancuso, C.; Tomasello, B.; Laura Ontario, M.; Cavallaro, A.; Frasca, F.; Maiolino, L.; Trovato Salinaro, A.; Calabrese, E.J.; Calabrese, V. Curcumin, Hormesis and the Nervous System. Nutrients 2019, 11, 2417. [CrossRef]

35. Leri, M.; Scuto, M.; Ontario, M.L.; Calabrese, V.; Calabrese, E.J.; Bucciantini, M.; Stefani, M. Healthy Effects of Plant Polyphenols: Molecular Mechanisms. Int. J. Mol. Sci. 2020, 21, 1250. [CrossRef]

36. Scuto, M.; Di Mauro, P.; Ontario, M.L.; Amato, C.; Modafferi, S.; Ciavardelli, D.; Trovato Salinaro, A.; Maiolino, L.; Calabrese, V. Nutritional Mushroom Treatment in Meniere's Disease with Coriolus versicolor: A Rationale for Therapeutic Intervention in Neuroinflammation and Antineurodegeneration. Int. J. Mol. Sci. 2019, 21, 284. [CrossRef]

37. Trovato Salinaro, A.; Pennisi, M.; Di Paola, R.; Scuto, M.; Crupi, R.; Cambria, M.T.; Ontario, M.L.; Tomasello, M.; Uva, M.; Maiolino, L.; et al. Neuroinflammation and neurohormesis in the pathogenesis of Alzheimer's disease and Alzheimer-linked pathologies: Modulation by nutritional mushrooms. Immun. Ageing 2018, 15, 8. [CrossRef]

38. Calabrese, V.; Butterfield, D.A.; Scapagnini, G.; Stella, A.M.; Maines, M.D. Redox regulation of heat shock protein expression by signaling involving nitric oxide and carbon monoxide: Relevance to brain aging, neurodegenerative disorders, and longevity. Antioxid. Redox Signal. 2006, 8, 444-477. [CrossRef] [PubMed]

39. Trovato, A.; Siracusa, R.; Di Paola, R.; Scuto, M.; Ontario, M.L.; Bua, O.; Di Mauro, P.; Toscano, M.A.; Petralia, C.C.T.; Maiolino, L.; et al. Redox modulation of cellular stress response and lipoxin A4 expression by HericiumErinaceus in rat brain: Relevance to Alzheimer's disease pathogenesis. Immun. Ageing 2016, 13, 23. [CrossRef]

40. Di Rosa, G.; Brunetti, G.; Scuto, M.; TrovatoSalinaro, A.; Calabrese, E.J.; Crea, R.; Schmitz-Linneweber, C.; Calabrese, V.; Saul, N. Healthspan Enhancement by Olive Polyphenols in C. elegans Wild Type and Parkinson's Models. Int. J. Mol. Sci. 2020, $21,3893$. [CrossRef] [PubMed]

41. Scuto, M.; Trovato Salinaro, A.; Modafferi, S.; Polimeni, A.; Pfeffer, T.; Weigand, T.; Calabrese, V.; Schmitt, C.P.; Peters, V. Carnosine activates cellular stress response in podocytes and reduces glycative and lipo-peroxidative stress. Biomedicines $2020,8,177$. [CrossRef]

42. Trovato, A.; Siracusa, R.; Di Paola, R.; Scuto, M.; Fronte, V.; Koverech, G.; Luca, M.; Serra, A.; Toscano, M.A.; Petralia, A.; et al. Redox modulation of cellular stress response and lipoxin A4 expression by Coriolus versicolor in rat brain: Relevance to Alzheimer's disease pathogenesis. Neurotoxicology 2016, 53, 350-358. [CrossRef]

43. Siracusa, R.; Scuto, M.; Fusco, R.; Trovato, A.; Ontario, M.L.; Crea, R.; Di Paola, R.; Cuzzocrea, S.; Calabrese, V. Article Antiinflammatory and Anti-oxidant Activity of Hidrox ${ }^{\circledR}$ in Rotenone-Induced Parkinson's Disease in Mice. Antioxidants 2020, $9,824$. [CrossRef] [PubMed]

44. Calabrese, V.; Scuto, M.; Salinaro, A.T.; Dionisio, G.; Modafferi, S.; Ontario, M.L.; Greco, V.; Sciuto, S.; Schmitt, C.P.; Calabrese, E.J.; et al. Hydrogen Sulfide and Carnosine: Modulation of Oxidative Stress and Inflammation in Kidney and Brain Axis. Antioxidants 2020, 9, 1303. [CrossRef]

45. Lo Dico, G.M.; Ulrici, A.; Pulvirenti, A.; Cammilleri, G.; Macaluso, A.; Vella, A.; Giaccone, V.; Lo Cascio, G.; Graci, S.; Scuto, M.; et al. Multivariate statistical analysis of the polyphenols content for the discrimination of honey produced in Sicily (Southern Italy). J. Food Compos. Anal. 2019. [CrossRef]

46. Amara, I.; Scuto, M.; Zappalà, A.; Ontario, M.L.; Petralia, A.; Abid-Essefi, S.; Maiolino, L.; Signorile, A.; Trovato Salinaro, A.; Calabrese, V. Hericium Erinaceus Prevents DEHP-Induced Mitochondrial Dysfunction and Apoptosis in PC12 Cells. Int. J. Mol. Sci. 2020, 21, 2138. [CrossRef] [PubMed]

47. López-Gutiérrez, N.; del Mar Aguilera-Luiz, M.; Romero-González, R.; Martínez Vidal, J.L.; Frenic, A.G. Fast analysis of polyphenols in royal jelly products using automated TurboFlow ${ }^{\mathrm{TM}}$-liquid chromatography-Orbitrap high resolution mass spectrometry. J. Chromatogr. B 2014, 973, 17-28. [CrossRef] [PubMed]

48. Wester, R.C.; Melendres, J.; Sedik, L.; Maibach, H.; Riviere, J.E. Percutaneous absorption of salicylic acid, theophylline, 2,4dimethylamine, diethyl hexyl phthalic acid, and p-aminobenzoic acid in the isolated perfused porcine skin flap compared to man in vivo. Toxicol. Appl. Pharmacol. 1998, 151, 159-165. [CrossRef]

49. Signorile, A.; Micelli, L.; De Rasmo, D.; Santeramo, A.; Papa, F.; Ficarella, R.; Gattoni, G.; Scacco, S.; Papa, S. Regulation of the biogenesis of OXPHOS complexes in cell transition from replicating to quiescent state Involvement of PKA and effect of hydroxytyrosol. Biochim. Biophys. Acta 2006, 1843, 675-684. [CrossRef]

50. De Rasmo, D.; Micelli, L.; Santeramo, A.; Signorile, A.; Lattanzio, P.; Papa, S. cAMP regulates the functional activity, coupling efficiency and structural organization of mammalian FOF1 ATP synthase. Biochim. Biophys. Acta 2016, 1857, 350-358. [CrossRef]

51. Morris, J.A.; Dorner, A.J.; Edwards, C.A.; Hendershot, L.M.; Kaufman, R.J. Immunoglobulin binding protein (BiP) function is required to protect cells from endoplasmic reticulum stress but is not required for the secretion of selective proteins. J. Biol. Chem. 1997, 272, 4327-4334. [CrossRef]

52. Ozcan, U.; Yilmaz, E.; Ozcan, L.; Furuhashi, M.; Vaillancourt, E.; Smith, R.O.; Görgün, C.Z.; Hotamisligil, G.S. Chemical chaperones reduce ER stress and restore glucose homeostasis in a mouse model of type 2 diabetes. Science 2006, 313, 1137-1140. [CrossRef] [PubMed]

53. Sharaf el dein, O.; Gallerne, C.; Deniaud, A.; Brenner, C.; Lemaire, C. Role of the permeability transition pore complex in lethal inter organelle crosstalk. Front. Biosci. 2009, 14, 3465-3482. [CrossRef]

54. Zhao, Y.; Li, M.Z.; Shen, Y.; Lin, Y.; Wang, H.R.; Talukder, M.; Li, J.L. Lycopene prevents DEHP-Induced Leydig Cell Damage with the Nrf2 Antioxidant Signaling Pathway in Mice. J. Agric. Food. Chem. 2020, 68, 2031-2040. [CrossRef] [PubMed] 
55. Głombik, K.; Basta-Kaim, A.; Sikora-Polaczek, M.; Kubera, M.; Starowicz, G.; Styrna, J. Curcumin influences semen quality parameters and reverses the di(2 ethylhexyl)phthalate (DEHP)-induced testicular damage in mice. Pharmacol. Rep. 2014, 66, 782-787. [CrossRef] [PubMed]

56. Helal, M.A. Celery oil modulates DEHP-induced reproductive toxicity in male rats. Reprod. Biol. 2014, 14, 182-189. [CrossRef]

57. Abd-Ellah, M.F.; Aly, H.A.; Mokhlis, H.A.; Abdel-Aziz, A.H. Quercetin attenuates di-(2-ethylhexyl) phthalate-induced testicular toxicity in adult rats. Hum. Exp. Toxicol. 2016, 35, 232-243. [CrossRef]

58. Li, J.; Zheng, L.; Wang, X.; Yao, K.; Shi, L.; Sun, X.; Yang, G.; Jiang, L.; Zhang, C.; Wang, Y.; et al. Taurine protects INS-1 cells from apoptosis induced by $\mathrm{Di}$ (2-ethylhexyl) phthalate via reducing oxidative stress and autophagy. Toxicol. Mech. Methods 2019, 4, 1-12. [CrossRef]

59. Kang, K.B.; Lee, K.H.; Chae, S.W.; Zhang, R.; Jung, M.S.; Lee, Y.K.; Kim, S.Y.; Kim, H.S.; Joo, H.G.; Park, J.W.; et al. Eckol isolated from Ecklonia cava attenuates oxidative stress induced cell damage in lung fibroblast cells. FEBS Lett. 2005, 79, 6295-6304. [CrossRef]

60. Mahaman, Y.A.R.; Huang, F.; Wu, M.; Wang, Y.; Wei, Z.; Bao, J.; Salissou, M.T.M.; Ke, D.; Wang, Q.; Liu, R.; et al. Moringa Oleifera Alleviates Homocysteine-Induced Alzheimer's Disease-Like Pathology and Cognitive Impairments. J. Alzheimers Dis. 2018, 63, 1141-1159. [CrossRef] [PubMed]

61. Jaafaru, M.S.; Nordin, N.; Shaari, K.; Rosli, R.; AbdullRazis, A.F. Isothiocyanate from Moringa oleifera seeds mitigates hydrogen peroxide-induced cytotoxicity and preserved morphological features of human neuronal cells. PLoS ONE 2018, 3, e0196403. [CrossRef] [PubMed]

62. Wang, F.; Bao, Y.; Shen, X.; Zengin, G.; Lyu, Y.; Xiao, J.; Weng, Z. Niazirin from Moringa oleifera Lam. attenuates high glucose-induced oxidative stress through PKC $\zeta /$ Nox4 pathway. Phytomedicine 2019, 8, 153066. [CrossRef] [PubMed]

63. Zhou, Y.; Yang, W.; Li, Z.; Luo, D.; Li, W.; Zhang, Y.; Wang, X.; Fang, M.; Chen, Q.; Jin, X. Moringa oleifera stem extract protect skin keratinocytes against oxidative stress injury by enhancement of antioxidant defense systems and activation of PPAR $\alpha$. Biomed. Pharmacother. 2018, 107, 44-53. [CrossRef] [PubMed]

64. Aju, B.Y.; Rajalakshmi, R.; Mini, S. Protective role of Moringa oleifera leaf extract on cardiac antioxidant status and lipid peroxidation in streptozocin induced diabetic rats. Heliyon 2019, 5, e02935. [CrossRef]

65. Goudarzi, M.; Haghi Karamallah, M.; Malayeri, A.; Kalantar, M.; Mansouri, E.; Kalantar, H. Protective effect of alpha-lipoic acid on di-(2-ethylhexyl) phthalate-induced testicular toxicity in mice. Environ. Sci. Pollut. Res. Int. 2020, 27, 13670-13678. [CrossRef]

66. Bahrami, N.; Goudarzi, M.; Hosseinzadeh, A.; Sabbagh, S.; Reiter, R.J.; Mehrzadi, S. Evaluating the protective effects of melatonin on di(2-ethylhexyl) phthalate-induced testicular injury in adult mice. Biomed. Pharmacother. 2018, 108, 515-523. [CrossRef]

67. Bahrami, N.; Mehrzadi, S.; Goudarzi, M.; Mansouri, E.; Fatemi, I. Lycopene abrogates di-(2-ethylhexyl) phthalate induced testicular injury by modulating oxidative, endocrine and inflammatory changes in mice. Life Sci. 2018, 15, 265-271. [CrossRef]

68. Lo, D.; Wang, Y.T.; Wu, M.C. Hepatoprotective effect of silymarin on di(2-ethylhexyl)phthalate (DEHP) induced injury in liver FL83B cells. Environ. Toxicol. Pharmacol. 2014, 38, 112-118. [CrossRef]

69. Paradies, G.; Paradies, V.; Ruggiero, F.M.; Petrosillo, G. Mitochondrial bioenergetics and cardiolipin alterations in myocardial ischemia/ reperfusion injury. Implications for pharmacological cardioprotection. Am. J. Physiol. Heart Circ. Physiol. 2018, 315, H1341-H1352. [CrossRef]

70. Marella, M.; Seo, B.B.; Yagi, A.M.; Yagi, T. Mechanism of Cell Death Caused by Complex I Defects in a Rat Dopaminergic Cell Line. J. Biol. Chem. 2007, 282, 24146-24156. [CrossRef]

71. De Rasmo, D.; Signorile, A.; Larizza, M.; Pacelli, C.; Cocco, T.; Papa, S. Activation of the cAMP cascade in human fibroblast cultures rescues the activity of oxidatively damaged complex I. Free Radic. Biol. Med. 2012, 52, 757-764. [CrossRef] [PubMed]

72. Dröse, S.; Brandt, U.; Wittig, I. Mitochondrial respiratory chain complexes as sources and targets of thiol-based redox-regulation1. Biochim. Biophys. Acta 2014, 1844, 1344-1354. [CrossRef]

73. Yu, H.-T.; Fu, X.-Y.; Liang, B.; Wang, S.; Liu, J.-K.; Wang, S.-R.; Feng, Z.-H. Oxidative damage of mitochondrial respiratory chain in different organs of a rat model of diet-induced obesity. Eur. J. Nutr. 2018. [CrossRef]

74. Suzuki, T.; Yamamoto, M. Stress-sensing mechanisms and the physiological roles of the Keap1-Nrf2 system during cellular stress. J. Biol. Chem. 2017, 292, 16817-16824. [CrossRef] [PubMed]

75. Basak, P.; Sadhukhan, P.; Sarkar, P.; Sil, P.C. Perspectives of the Nrf-2 signaling pathway in cancer progression and therapy. Toxicol. Rep. 2017, 4, 306-318. [CrossRef] [PubMed]

76. Hetz, C. The unfolded protein response: Controlling cell fate decisions under ER stress and beyond. Nat. Rev. Mol. Cell Biol. 2012, 13, 89-102. [CrossRef] [PubMed]

77. Glover-Cutter, K.M.; Lin, S.; Blackwell, T.K. Integration of the unfolded protein and oxidative stress responses through SKN-1/Nrf. PLoS Genet. 2013, 9, e1003701. [CrossRef]

78. Gardner, B.M.; Pincus, D.; Gotthardt, K.; Gallagher, C.M.; Walter, P. Endoplasmic Reticulum Stress Sensing in the Unfolded Protein Response. Cold Spring Harb. Perspect. Biol. 2013, 5, a013169. [CrossRef] [PubMed]

79. Sano, R.; Reed, J.C. ER stress-induced cell death mechanisms. Biochim. Biophys. Acta 2013, 1833, 3460-3470. [CrossRef]

80. Im, J.S.; Na Lee, H.; Oh, J.W.; Yoon, Y.J.; Park, J.S.; Park, J.W.; Kim, J.H.; Kim, Y.S.; Cha, D.S.; Jeon, H. Moringa oleifera Prolongs Lifespan via DAF-16/FOXO Transcriptional Factor in Caenorhabditis elegans. Nat. Prod. Sci. 2016, 22, 201-208. [CrossRef]

81. Peropadre, A.; Fernández Freire, P.; Pérez Martín, J.M.; Herrero, Ó.; Hazen, M.J. Endoplasmic reticulum stress as a novel cellular response to di (2-ethylhexyl) phthalate exposure. Toxicol. Vitro 2015, 30, 281-287. [CrossRef] [PubMed] 
82. Joung, H.; Kim, B.; Park, H.; Lee, K.; Kim, H.H.; Sim, H.C.; Do, H.J.; Hyun, C.K.; Do, M.S. Fermented Moringa oleifera Decreases Hepatic Adiposity and Ameliorates Glucose Intolerance in High-Fat Diet-Induced Obese Mice. J. Med. Food 2017, $20,439-447$. [CrossRef] [PubMed]

83. Zinszner, H.; Kuroda, M.; Wang, X.; Batchvarova, N.; Lightfoot, R.T.; Remotti, H.; Stevens, J.L.; Ron, D. CHOP is implicated in programmed cell death in response to impaired function of the endoplasmic reticulum. Genes Dev. 1998, 12, 982-995. [CrossRef]

84. Santos, X.C.; Tanaka, L.Y.; Wosniak, J., Jr.; Laurindo, R.M. Mechanisms and Implications of Reactive Oxygen Species Generation During the Unfolded Protein Response: Roles of Endoplasmic Reticulum Oxidoreductases, Mitochondrial Electron Transport, and NADPH Oxidase. Antioxid. Redox Signal. 2009, 11, 2409-2427. [CrossRef] [PubMed]

85. Lucero, M.; Suarez, A.E.; Chambers, J.W. Phosphoregulation on mitochondria: Integration of cell and organelle responses. CNS Neurosci. Ther. 2019, 25, 837-858. [CrossRef] [PubMed]

86. Wu, W.; Zhou, X.; Liu, P.; Fei, W.; Li, L.; Yun, H. Isoflurane reduces hypoxia/reoxygenation-induced apoptosis and mitochondrial permeability transition in rat primary cultured cardiocytes. BMC Anesthesiol. 2014, 14, 17. [CrossRef]

87. Newcomb-Fernandez, J.K.; Zhao, X.; Pike, B.R. Concurrent assessment of calpain and caspase-3 activation after oxygen-glucose deprivation in primary septo-hippocampal cultures. J. Cereb. Blood Flow Metab. 2001, 21, 1281-1294. [CrossRef]

88. Abdul Hisam, E.E.; Rofiee, M.S.; Khalid, A.M.; Jalaluddin, A.F.; Mohamad Yusof, M.I.; Idris, M.H.; Ramli, S.; James, R.J.; Jack Yoeng, W.; Lay Kek, T.; et al. Combined extract of Moringa oleifera and Centellaasiatica modulates oxidative stress and senescence in hydrogen peroxide-induced human dermal fibroblasts. Turk. J. Biol. 2018, 42, 33-44. [CrossRef] 